\title{
Sarah Livingston Jay, 1756--1802: Dynamics of power, privilege and prestige in the Revolutionary era
}

Jennifer Megan Janson

West Virginia University

Follow this and additional works at: https://researchrepository.wvu.edu/etd

\section{Recommended Citation}

Janson, Jennifer Megan, "Sarah Livingston Jay, 1756--1802: Dynamics of power, privilege and prestige in the Revolutionary era" (2005). Graduate Theses, Dissertations, and Problem Reports. 797.

https://researchrepository.wvu.edu/etd/797

This Thesis is protected by copyright and/or related rights. It has been brought to you by the The Research Repository @ WVU with permission from the rights-holder(s). You are free to use this Thesis in any way that is permitted by the copyright and related rights legislation that applies to your use. For other uses you must obtain permission from the rights-holder(s) directly, unless additional rights are indicated by a Creative Commons license in the record and/ or on the work itself. This Thesis has been accepted for inclusion in WVU Graduate Theses, Dissertations, and Problem Reports collection by an authorized administrator of The Research Repository @ WVU. For more information, please contact researchrepository@mail.wvu.edu. 
Sarah Livingston Jay, 1756-1802: Dynamics of Power, Privilege and Prestige in the Revolutionary Era

\author{
Jennifer Megan Janson
}

Thesis submitted to the Eberly College of Arts and Sciences at West Virginia University in partial fulfillment of the requirements for the degree of

\author{
Master of Arts \\ in \\ Colonial and Revolutionary History \\ Robert Blobaum, Ph.D., Department Chair \\ Mary Lou Lustig, Ph.D., Committee Chair \\ Ken Fones-Wolf, Ph.D. \\ John Super, Ph.D. \\ Department of History
}

Morgantown, West Virginia 2005

Keywords: Sarah Livingston Jay, American Revolution, John Jay, Women's History, Domesticity, Patriotism Copyright 2005 Jennifer Megan Janson 


\begin{abstract}
Sarah Livingston Jay, 1756-1802: Dynamics of Power, Privilege and Prestige in the Revolutionary Era

Jennifer Megan Janson
\end{abstract}

Sarah Livingston Jay was a politically astute woman whose contributions to the success of the American Revolution and reconstruction of post-war society have long been underestimated. She understood the complex political and financial dynamics beneath the decision to declare independence from Great Britain and the international alliances necessary for success. Intelligent, educated and socially skilled, she used her personal gifts, position, and familial connections to exert a strong influence on the course of events that would benefit her fledgling country. She used her social graces to take part in the male-dominated political world, while working within the domestic realm. She was not the only female patriot to make a significant contribution to the patriot cause. She was a prominent representative figure of a larger group of women whose roles in the revolution and the formation of the United States of America have been ignored, understated or viewed as inconsequential. 


\section{Acknowledgements}

The list of those of aided in and influenced this work is short, but that is not to understate their contributions and help. Without their heartfelt support, love, and encouragement it is difficult to imagine the completion of this thesis.

Gregory and Katharine Janson

Jeffrey Lawrence and Joan Perey

Stephen N. Bokone, Jr.

Katherine Trimmier

Dr. Mary Lou Lustig 


\section{Table of Contents}

Introduction: Research and Methodology: 5-19

एவாए

Chapter One: A Life of Privilege and Patriotism: 20-30

एவாவ

Chapter Two: Sarah Livingston Jay 1779-1784, A Patriot Within the Bounds of Domesticity: 31-56

வாவா

Chapter Three: The Queen of America's Return: 57-77

ேவாவ

Conclusion: $78-82$ 
Introduction: Research and Methodology 
Sarah Livingston Jay was a politically astute woman whose contributions to the success of the American Revolution and reconstruction of post-war society have long been underestimated. She understood the political and financial dynamics that underlay the decision to declare independence from Great Britain and the fragile, complex subtleties that formed personal and international alliances necessary for success. Intelligent, educated and socially skilled, she used her personal gifts, her position, and her familial connections to exert an influence on the course of events that would benefit her fledgling country. Sarah Livingston Jay was a dedicated patriot during and after the American Revolution. She used her social graces to take part in the male-dominated political world, while working within the domestic realm. Mrs. Jay was not the only female patriot to make a significant contribution to the patriot cause. She was a prominent representative figure of a larger group of women whose roles in the revolution and the formation of the United States of America have been ignored, understated or viewed as inconsequential.

Sarah Jay did not expound feminist views, write books or pamphlets, or speak publicly as did her male counterparts. Neither did she commit any other "untoward" act that violated the cultural norms of colonial domesticity. Expressions of her patriotism can be found in the numerous private sacrifices she made for the American Revolution, as did many of her female contemporaries. These women chose to risk their lives, personal security, and the well-being of their children and family for their ideals.

Sarah Jay was unique in her decision to accompany her husband to Europe: she was the only wife of a diplomat during the war to travel abroad with her spouse. She left her only son behind, buried her second child on foreign soil, gave birth to a third, and 
faced loneliness and isolation without the comfort of her family and often without the physical presence of her husband, John Jay. She advocated for the colonies while learning the art of European politics and the subtleties of social alliances that often ensured political ends. In Europe, she learned the social graces she used so effectively when she and her husband returned to the United States. Socially, she and John Jay epitomized the height of elegant late eighteenth-century New York society. Sarah Jay raised her family, handled their financial affairs, was knowledgeable of politics and aptly mediated difficult situations that arose at the family home, Bedford Farm, during its construction.

Throughout the war and after, Mrs. Jay embraced her domestic role. Rather than rejecting her responsibilities as wife and mother, she performed them while taking on new spheres of influence. She acquired a great deal of practical political power, made possible because of the American Revolution and its resultant social upheaval. She was an unrecognized diplomat without a portfolio. The steely intelligence, passionate commitment and moral fiber she exhibited as a patriot served her family well. Sarah Jay was able to combine domestic virtues, intellectual acumen and political activism, a set of roles with which feminists struggle today. Sarah Jay was representative of the way women, whose roles were bound by the limits of culture and convention, exerted their influence during and after the American Revolution within the realm of politics and political power.

A review of the literature serves to provide insight into how women of the revolutionary period were perceived and their actions recorded, for women do have unique and identifiable experiences that differ from their male counterparts that are often 
overlooked. Two books can be taken as representative of most revolutionary histories.

The first is John Ferling's book, A Leap in the Dark: The Struggles to Create the American Republic (2003), a modern day historical work that ignores the contributions of women while extolling the virtues of the "founding fathers." A Leap in the Dark discusses the American Revolution and success of the colonies in their war against Great Britain, yet it excludes women and their contributions to the struggle. Using the male experience as universal is problematic for women's perceptions as a group vary greatly due to culturally constructed gender differences, as well as physical, morphological, and anatomical differences. Ferling fails to mention such women as Esther DeBerdt Reed, who organized the collection of funds for George Washington's troops, and the Daughters of Liberty, who aided the patriot cause through several methods, including making homespun cloth. A Leap in the Dark (2003) does not take into consideration the overall and significant impact that women had in the struggle for independence. Women and their actions are only mentioned in conjunction with men, such as fathers and husbands. ${ }^{1}$ This failing reflects a fundamental flaw in most historical investigations and raises ethical questions as well: what harm does an historian do by excluding or marginalizing groups of people?

Carl Bridenbaugh, in The Spirit of '76: The Growth of American Patriotism Before Independence (1975), chronicles the growth of patriotism before the war as a male-only endeavor. The patriotism of women is not questioned in Bridenbaugh's book: it is simply not mentioned. When the author uses term like "colonists" he is referring to

\footnotetext{
${ }^{1}$ John Ferling, A Leap in the Dark: The Struggles to Create the American Republic (Oxford: Oxford University Press, 2003).; Nancy F. Cott and Elizabeth H. Pleck. "Introduction" In A Heritage of Her Own: Toward a New Social History of American Women, edited by Nancy F. Cott and Elizabeth H. Pleck, 13-17 (New York: Simon and Schuster, 1979).; Merry E. Wiesner-Hanks, Gender in History (Oxford: Blackwell Publishers, 2001), 1-8.
} 
male colonists. It is interesting to note that over a quarter of a century later, the same problematic areas in most historical works, such as Ferling's and Bridenbaugh's, continue. $^{2}$

The reason for this neglect of women by many historians stem from the once commonly held belief that historical source works by women did not exist. Written records by women $d o$ exist but are often catalogued under the names of male family members and friends. Much correspondence, diaries, and other written material remain unknown. ${ }^{3}$ Mrs. Jay's letters are primarily found in the collected correspondence of William Livingston or John Jay. Sarah Jay's letters are available in John Jay: The Making of a Revolutionary, Unpublished Papers, 1745-1780 (1975) and John Jay: The Winning of the Peace, Unpublished Papers 1780-1784 (1980), both edited by Richard B. Morris. These volumes contain numerous letters between Sarah Jay and her husband, family and friends. The notations in these volumes provided other avenues of research and the commentary by Richard B. Morris helps to place the letters in a historical time frame. ${ }^{4}$

\footnotetext{
${ }^{2}$ Carl Bridenbaugh, The Spirit of '76: The Growth of American Patriotism Before Independence (New York: Oxford University Press, 1975).; Cott, 13-17. Past historical works that centered on women, as well as many today, tend to concentrate on three key areas identified by Cott and Pleck. The first of these areas is institutional histories of women's organizations, which implied that women deserved recognition only when they took on typically male roles. The second is biographies of women that highlight their accomplishments while failing to connect their greater influence on society and confining them to their immediate surroundings, identifying them as unusual. The third category is when historians mistake perception for reality, such as culturally designated female roles, either within the family or society. One example of this can be seen in Elizabeth Evan's Weathering the Storm: Women of the American Revolution (New York: Charles Scribner's Sons, 1975), which portrayed eleven women, yet failed to connect them to their influence upon society. A second example is Melissa Lukeman Bohrer's Glory, Passion, and Principle: The Story of Eight Remarkable Women at the Core of the American Revolution (New York: Atria Books, 2003), who only described women that were she considered "unusual".

${ }^{3}$ Keller, Rosemary, Patriotism and the Female Sex: Abigail Adams and the American Revolution (New York: Carlson Publishing Inc., 1994), X.

${ }^{4}$ Richard B. Morris, ed., John Jay: The Making of a Revolutionary, Unpublished Papers 1745-1780, Vol. 1 (New York: Harper \& Row, Publishers, 1975).; Richard B. Morris, ed., John Jay: The Winning of the Peace, Unpublished Papers, 1780-1784, Vol. 2 (New York: Harper \& Row, Publishers, 1980).
} 
Even a cursory reading of the Jays' correspondence within these volumes suggests a rich and rewarding emotional connection between the husband and wife, and with family and an extended network of friends. Sarah's letters artfully combine genuine affection with a strong character that is consistently courageous, patriotic, and politically shrewd. She exhibited great personal and moral heroism during and after the war and cleverly used her wealth, her social connections, and her "womanly" skills to solidify and secure the Jays' place in New York society. The letters within the available compendiums suggest that Sarah lived a life of ideas, that she was an ambitious woman who knew exactly what she wanted. However, the letters also demonstrate that the love and affection of her family were important to her. Sarah understood her roles as wife, mother, daughter, sister, and woman with uncanny perception in an era that sought to rigidly define the functions, responsibilities and behaviors of women, regardless of position and privilege.

Another sterling source of Sarah Jay's letters is the Correspondence by or to the First Chief Justice of the United States and His Wife: John Jay and Sarah Livingston Jay (2005), edited by Janet M. Wedge, Landa M. Freeman, and Louise V. North. ${ }^{5}$ Other primary resources include The Papers of John Jay, 1745-1829. Edited by Jean Ashton, this online compilation of letters of John Jay's letters includes those to his wife and by her to family members and friends. The site proved invaluable in checking the accuracy of letters published elsewhere and for providing access to letters previously unpublished. The major limitation of this archive is the letters are scanned onto the website, making it

\footnotetext{
${ }^{5}$ Landa M. Freeman, Louise V. North, and Janet M. Wedge, ed., Selected Letters of John Jay and Sarah Livingston Jay: Correspondence by or to the First Chief Justice of the United States and His Wife (Jefferson, North Carolina: McFarland \& Company, Inc., Publishers, 2005).
} 
difficult and time consuming to read them. More letters were found within The Papers of William Livingston. ${ }^{6}$

One should keep in mind when using the compilations of letters that many of the Jays' individual letters are not sequential and may seem disjointed, which can create confusion due to the unreliable nature of mail delivery. Many of the letters written between Sarah and John Jay were never delivered. ${ }^{7}$ John and Sarah Jay were well aware of the problems associated with the colonial mail service and the transatlantic mail service. While John and Sarah Jay were in Spain and France on diplomatic missions their letters had to be crafted to avoid prying eyes. When John Jay found himself in financial straits in Spain he was forced to send his official dispatches through the public mail system, where his letters were often opened and read. He often wrote his letters in a secret code to protect their content. Sarah Jay did not use a code when writing, but she did exercise prudence and cautiousness. ${ }^{8}$ While in Spain, Sarah wrote to her mother, Susannah French Livingston: "Letters are no longer the free medium by which distant friends un-bosom themselves to each other; every thing therefore that prudence bids us suppress at present, we'll entertain ourselves with when sitting together by an American fire-side." $" 9$

Penmanship and use of language in the correspondence between Sarah and John is yet another factor than must be considered when reading their letters. In late eighteenth-

\footnotetext{
${ }^{6}$ Carl E. Prince, Dennis P. Ryan, Brenda Parnes, and Mary Lou Lustig, ed., The Papers of William Livingston: January 1779 - June 1780, Vol. 3 (New Brunswick: Rutgers University Press, 1986).; Carl E. Prince and Mary Lou Lustig, ed., The Papers of William Livingston: July 1780-April 1783, Vol. 4 (New Brunswick and London: Rutgers University Press, 1987).; Jean Ashton, ed., The Papers of John Jay, 1745 1829 [webpage][November 24, 2004] Columbia University; available from $<$ http:www.Columbia.edu/cu/lweb/eresources/archives/jay/>.

${ }^{7}$ Freeman, 16-20.

${ }^{8}$ Freeman, 16, 18.; Sally Smith Booth, The Women of '76 (New York: Hastings House, 1973), 215-16.

${ }^{9}$ Sarah Livingston Jay to Susannah French Livingston, 28 August 1780, in Unpublished Papers, Vol. 1, 709-712.
} 
century America letter writing was considered a genteel pursuit, a personal reflection on the elegance and sophistication of the writer. Many wealthy and privileged persons in Colonial America worked hard to achieve style and grace in their penmanship and master formal usage that might seem awkward by modern standards. Careful study of what were considered "model" letters with excellent penmanship and sophisticated language was a commonplace practice. A fair hand and use of the intricate formal language was considered indicative of social station, education, and over-all good breeding. ${ }^{10}$

Volume one and two of The Life of John Jay: with Selections From His Correspondence and Miscellaneous Papers, edited by William Jay and published in 1833, contains few letters to or from Sarah Livingston Jay. Less useful was A Memoir of the Life of William Livingston: Extracts From His Correspondence, and Notices of Various members of His Family, 1774-1790, published in 1833 and edited by Theodore Sedgewick, Jr. This memoir concentrated on public events and many private letters were not included in the works that were meant to be political portraits of William Livingston and John Jay. ${ }^{11}$

Although no full length study of Sarah Jay exists, three books in particular were excellent sources. The first was Born for Liberty: A History of Women in America (1989) by Sara M. Evans. This work provided excellent insights into women and the roles they played before, during and after the American Revolution. It delves into the political

\footnotetext{
${ }^{10}$ Freeman, 16-18.

${ }^{11}$ William Jay, ed., The Life of John Jay: with Selections From His Correspondence and Miscellaneous Papers, Vol. 1 (New York: J\&J Harper, 1833); William Jay, ed., The Life of John Jay: with Selections From His Correspondence and Miscellaneous Papers, Vol. 2 (New York: J\&J Harper, 1833); Theodore Sedgewick, Jr., ed., A Memoir of the Life of William Livingston: Extracts From His Correspondence, and Notices of Various members of His Family, 1774-1790 (New York: J\&J Harper, 1833.
} 
consciousness of women during this time period, but is not well defined. ${ }^{12}$ Linda K.

Kerber's Women of the Republic: Intellect \& Ideology in Revolutionary America (1986),

provides keen insights into the rise of political consciousness of women during the

American Revolution and the roles they fulfilled from mid to late eighteenth century.

Liberty's Daughters: The Revolutionary Experience of American Women, 1750-1800

(1980) by Mary Beth Norton, provides a detailed account of the lives of colonial women during this time period. ${ }^{13}$ Other works that included helpful notations were the bibliographic article "Sarah Van Brugh Livingston Jay, 1756-1802," in Past and Promise: Lives of New Jersey Women(1990), edited by Claire McCurdy. Other useful sources were Cokie Robert's Founding Mothers: The Women Who Raised Our Nation (2004) and Stephen Birmingham's America 's Secret Aristocracy (1987). ${ }^{14}$

Other treatments of Sarah Jay can be found in the many books about John Jay. These books mention Sarah Jay, such as Yankees at the Court: The First Americans in Paris (1982), by Susan Mary Alsop, which paints a detailed portrait of the Jays in Paris. Frank Monaghan's John Jay: Defender of Liberty (1935) provides useful information regarding the late eighteenth century political relationship between Spain, France, and America. ${ }^{15}$ Pauline Scholoesser's The Fair Sex: White Women and Racial Patriarchy in

\footnotetext{
${ }^{12}$ Sarah M. Evans, Born for Liberty: A History of Women in America (New York: The Free Press, A Division of Macmillan, Inc., 1989).

${ }^{13}$ Linda K. Kerber, Women of the Republic: Intellect \& Ideology in Revolutionary America (New York: W.W. Norton \& Company, 1986).; Mary Beth Norton, Liberty's Daughters: The Revolutionary Experience of American Women, 1750-1800 (Boston-Toronto: Little, Brown, and Company, 1980).

${ }^{14}$ Claire McCurdy, "Sarah Van Brugh Livingston Jay, 1756-1802) in Past and Promise: Lives of New Jersey Women, ed. Joan N. Burstyn (New Jersey: The Scarecrow Press, Inc., 1990).; Cokie Roberts, Founding Mothers: The Women Who Raised Our Nation (New York: HarperCollins, 2004).; Stephen Birmingham, America's Secret Aristocracy (Boston: Little, Brown \& Company, 1987).

${ }^{15}$ Frank Monaghan, John Jay: Defender of Liberty (New York: The Bobbs-Merrill Company, 1935).; Susan Mary Alsop, Yankee's at the Court: The First American in Paris (New York: Doubleday and Company, Inc., 1982).
} 
the Early American Republic (2002) aided in understanding the societal expansion and societal strictures placed upon women during the late eighteenth century. ${ }^{16}$

The American Revolution was a period of constant social change, in large part due to the social turmoil and chaos created by war. Sarah Livingston Jay, as well as other American women, faced new challenges and necessity dictated the redefinition or shifting of assigned gender roles found within the colonies. A significant part of the process was the development of a political consciousness among women that would continue long after the war's end. The American Revolution created opportunities for women to participate in politics in a new way, one that expanded their political consciousness. ${ }^{17}$

Politically important positions, previously closed to them, materialized for women such as Sarah Livingston Jay, for the American Revolution created ambiguity regarding civilian roles, particularly those of women. The rules were no longer clear when crown authority was being challenged and great and terrible battles were being fought in the streets of American cities and the backyards of American farms. A trusted neighbor might be sympathetic to the rebellion or loyal to the Crown. Forfeiture of property and life now rested on knowing the political heart of one's neighbor. Neutrality was no longer a viable personal or political option. ${ }^{18}$

The actions of Sarah Livingston Jay during the war and after, permissible due to the changes in society caused by the war, helps to further discredit the assumption among

\footnotetext{
${ }^{16}$ Pauline Scholoesser, The Fair Sex: White Women and Racial Patriarchy in the Early American Republic (New York: New York University Press, 2002).; For more examples and information regarding gender and history, see Alfred Young, "The Women of Boston: "Persons of Consequence" in the Making of the American Revolution, 1765-1776," in Women and Politics in the Age of Democratic Revolution", Harriet B. Applewhite and Darline G. Levy, ed. (Ann Arbor: The University of Michigan Press, 1990), 181-218 and John F. Berens, Providence and Patriotism in Early America, 1640-1815 (Charlottesville: University Press of Virginia, 1978) and Sally Smith Booth, The Women of '76 (New York: Hastings House, 1973).

${ }^{17}$ Young, 181-218.; Elizabeth Evans, Weathering the Storm: Women of the American Revolution (New York: Charles Scribner's Sons, 1975), 2-4.; Kerber, 105.; Evans, S., 46.

${ }^{18}$ Evans, E., 2-4.; Evans, S., 46.
} 
historians prior to the 1980s that during the American Revolution, the political identity of women was solely defined by their fathers, husbands and brothers. This assumption reflects the popular attitudes of colonial times: men believed that women were not capable of understanding complex political issues. This simplistic view was further supported by eighteenth-century political theorists who argued that political thought and participation in the public sphere was the exclusive domain of males in Revolutionary and post-Revolutionary America. ${ }^{19}$

Like Sarah Livingston Jay, many women who created a political identity during the revolution did so without abandoning their domestic roles and responsibilities. Despite their best efforts to craft a political awareness that blended the public and domestic spheres, they were ultimately unsuccessful since they lacked the franchise: women were not voting citizens and were prohibited by law from full participation in the legislative and political decision-making process that guided their lives. Yet Sarah Livingston Jay was eminently successful in that she worked within the domestic sphere and never challenged her role. ${ }^{20}$

Many women, such as Sarah Jay, developed a political consciousness during the war. Subordinate legal status left women of eighteenth-century America with virtually no individual rights under the law. Women had little control over their lives, were bound by the archaic marriage laws of femme covert, and were excluded from politics. Women had only minimal access to the defined political forums that were essential to the formation of men's political attitudes. These establishments consisted of the meeting house, the town meeting hall, the public schools, and the militia. Of these four, only the

\footnotetext{
${ }^{19}$ Kerber 34-8.

${ }^{20}$ Kerber, 35-6.
} 
church was open to women, and women took advantage of that arena to strengthen their relationships and their social networks. Reduced political awareness was also exacerbated by the lower literacy rate among women. Unable to read the content of the many pamphlets and newspaper articles written before and during the revolution, many women obtained their information second-hand. Sarah Jay, who was able to read and write, did not experience these problems, for she was raised in a politically active household. ${ }^{21}$

The Revolution affected every aspect of American life, including attitudes and values regarding gender that allowed Sarah Jay and other women to act forcefully. For example, prior to the American Revolution few petitions were written or signed by women. The first recorded political act by a group of women in the pre-revolutionary era was a petition written and signed by fifty-one women of Edenton, North Carolina dated October 25, 1774. This petition endorsed the Non-Importation Association's resolves released earlier in the year. The petitioners vowed to uphold the non-consumption codes for the "publick good." In their petition, the women stated that upholding the codes was their duty because it affected their "near and dear relations and connections."22 In the colonies and in England, the petition was scorned as "unladylike." ${ }^{23}$ Arthur Iredell, an Englishman, in a letter to a North Carolinian relative, demonstrated the common reaction in England to the pamphlet when he wrote "Is there a Female Congress at Edenton too? I hope not, for we Englishmen are afraid of the Male Congress, but...the Ladies...have

\footnotetext{
${ }^{21}$ Young, 181-218.; Evans, E., 2-4.; Kerber, 105.; Evans, S., 46.

${ }^{22}$ Alice M. Earle, Colonial Dames and Good Wives (New York: The Macmillan Company, 1895), 240-41.; Earle, 240-41.; Kerber, 38-41.; As quoted in Earle, 253-54.

${ }^{23}$ Earle, 241.; Kerber, 41.; Evans, S., 49-50.
} 
ever, since the Amazonian Era, been esteemed the most formidable Enemies." ${ }^{24}$ Despite the condescending remarks made by Iredell and others, women in pre-Revolutionary America were beginning to form a distinct political identity within their appointed realm. ${ }^{25}$ This newly formed political identity took many forms. The outbreak of the American Revolution and the signing of the Declaration of Independence allowed some women to move beyond more passive activities that involved self-definition and identification into a more politically active role. Although Sarah Livingston Jay was raised in a political household, the outbreak of the American Revolution allowed for the creation of a broader domestic circle that she worked within to achieve her goals and allowed her political consciousness to burgeon. ${ }^{26}$

A small percentage of women began to write and publish pamphlets either for or against independence from Great Britain. The Sentiments of an American Woman, a broadside published in Philadelphia on June 10,1780 was followed by the Broadside of the Ladies of Trenton, which appeared in the New Jersey Gazette on July 12, 1780. The latter claimed that women were "born for liberty, distaining to bear the irons of a tyrannic Government" and that they would better serve their country if "opinion and manners did not forbid [them] to march to glory by the same paths as the men."27 This quotation combines patriotic sentiment and commitment with a clear acknowledgement of their understanding of the limitations placed upon them by the men of the colonies. Yet, they go on to write that they wish to "display the same sentiments which animated us at the beginning of the Revolution, when we renounced the use of teas... when our republican

\footnotetext{
${ }^{24}$ Evans, S., As quoted page 49-50.

${ }^{25}$ Young, 181-218.

${ }^{26}$ Young, 181-218.

${ }^{27}$ Evans, S., as quoted on page 50.
} 
and laborious hands spun the flax, prepared linen intended for the use of our soldiers; when exiles and fugitives, we supported with courage all the evils which are the concomitants of war."28 They understood the significance of their actions as well as the political implications. Six years earlier, for women to simply publish a pamphlet had been considered scandalous. By 1780, these new pamphlets made the broadsides published by the Edenton Ladies Association in 1776 seem quite tame. Steeled by war, the female authors of these later writings communicated more radical revolutionary thoughts and a deeper understanding of the political environment of the colonies. Unlike earlier publication efforts, these new writings were well received and generally accepted by the population as an appropriate expression of patriotic passion. Sarah Jay did not write pamphlets or participate in the war through public actions, but the changing attitudes towards gender in the colonies during the war allowed her to expand her political consciousness without repercussions within the realm of domesticity.

Many patriotic women, including Sarah Livingston Jay, were raised in political families and married men of similar political ideals. Abigail Adams also numbered among these women. Nearly all of these women had received some degree of education during their childhood. Seldom did these upper class women nurse, spy, or collect funds for troops. Nonetheless, they made momentous personal sacrifices for the American Revolution, involving great personal risk. Many American women could—and did—actively support the American Revolution without leaving their domestic circles. ${ }^{29}$

Sarah Livingston Jay was a part of these politically conscious circles of patriotic women by birthright and connection. Her approach was more consistent with the rather

\footnotetext{
${ }^{28}$ Ibid.

${ }^{29}$ Kerber, 76.
} 
conservative gender script assigned to her, leading her to fulfill a different role than those of many of the women during the revolution. A number of women crossed gender lines to step into roles that were culturally designated as being exclusively male roles, and in doing so, publicly usurped traditional male prerogatives or they expounded views that were inconsistent with their domestic roles. Sarah Livingston Jay, on the other hand, embraced her role in society and worked within its confines. ${ }^{30}$

Sarah Livingston Jay was wealthy, white, and educated, which placed her in a special societal position in the colonies before and after the war. The great majority of white American women did not fit into this category nor did African Americans or Amerindians. While Sarah Livingston Jay was not normative of the majority of colonial females she represented a larger number of women than previously believed, and as such is an example that should be understood in the appropriate context.

Sarah Livingston Jay was a major contributor to the revolutionary war on a par with her male counterparts. Mrs. Jay exemplifies a previously dim cadre of women who participated in the American Revolution, the political arena, and the shaping of post-war America, even as they remained within the realm of domesticity, using the restrictions placed upon them by society to their advantage. The dynamics of power, prestige, and influence had a greater effect upon women of this time period than previously believed. Even a brief survey of her life provides a unique and balanced perspective on women's participation in the political life of an emerging eighteenth century nation.

\footnotetext{
${ }^{30}$ Ibid.
} 
Chapter One: A Life of Privilege and Patriotism 
Sarah Livingston Jay was born in 1756, a period of political turmoil that would lead to the American Revolution. The war influenced both societies' attitudes toward gender and toward Sarah Jay, who worked within the expanded bounds of domesticity for the cause of the American Revolution. Years of prosperous economic trade in New York and New Jersey prior to the American Revolution gave rise to a privileged and influential social class that sought to imitate the perceived cultural superiority of the English elite. By 1750, metropolitan New York was the cultural heart of the new colonial aristocracy. Great wealth created great demands for women who were able to meet societal expectations not just as a wife and mother, but also as perfect "gentlewomen." This was a role requiring a degree of sophistication and knowledge that could only be gained through education. Accordingly, the training and education of daughters became a critical prerequisite for enhancing marriageability and attracting a husband worthy of a familial alliance. Education, the demand for poise and sophistication, and the importance of functioning "gentlewomen" created a unique place in Pre-Revolutionary American society for many women, despite the fact that even the wealthiest of married women had little legal power. ${ }^{31}$

Sarah Livingston Jay was born into one of the most wealthy and powerful families in New York. These families, unlike many colonial families, valued education. They believed intelligent females contributed to the formation of good moral values, because they passed these values on to their children. Many educated and intelligent women emerged as politically conscious and enthusiastic Patriots and Loyalists as the war approached. Throughout the American Revolution these women exerted a growing

\footnotetext{
${ }^{31}$ Cynthia A. Kierner, "From Entrepreneurs to Ornaments: The Livingston Women, 1679-1790" in The Livingston Legacy: Three Centuries of American History, ed. Richard T. Wiles, 337, 340, 347 (Taconic Region: Bard College, 1987).
} 
influence, recognizing in themselves a mounting political consciousness despite the strong cultural inhibitions that clearly defined their roles in the domestic, rather than the political, sphere. Whether by intention or as a result of war, by the end of the American Revolution many women held strong political convictions which they were willing to express. $^{32}$

Sarah Livingston's childhood and adolescence were designed to educate and prepare her for the social and political roles she played during and after the war. Born into the influential and socially elite Livingston family of New York on August 2, 1756, Sarah Livingston was one of five surviving children of William and Susannah French Livingston. Sarah's education was informal, but rigorous. Primarily educated by her parents, she learned reading, writing, dancing, proper etiquette, sewing, knitting, and household management. Sarah also received an impromptu political education from simply living in the Livingston household: William Livingston was a well-known lawyer and a politically active member of the Whig party. The foremost polemicist in New York, he was an outspoken Whig who despised the injunctions and restrictions placed upon the colonies by Parliament. In the decades preceding the American Revolution he was one of the "New York Triumvirate," along with William Smith, Jr., and John Morin Scott. The trio "kept the New York political kettle aboil by their opposition to crown measures. ${ }^{, 33}$ Tired of the constant turmoil that characterized New York politics, in 1770 William Livingston retired from his legal practice and moved his family to his new estate, Liberty Hall, in Elizabeth Town, New Jersey, where he hoped to live a quiet life. The outbreak of the revolution, however, rejuvenated his political career and he accepted

\footnotetext{
${ }^{32}$ Kierner, 337, 340, 347.

${ }^{33}$ McCurdy, 24-26.; Freeman, 291.; Morris, Vol. 1, 123.
} 
a recall to public duty, serving as governor of the state until his death in 1790. In this politically charged atmosphere the courtship between Sarah Livingston, who was barely fifteen years old, and her future husband, John Jay, began. It was Sarah's uncle, Robert Livingston, Jr., a business partner of Jay, who introduced the couple. ${ }^{34}$ John Jay was an eminent barrister, a graduate of King's College (now Columbia University) and a member of a well-known New York mercantile family. The Jay family, including John, was politically conservative. They feared a revolution would lead to a government ruled by the lower sort. Should this happen the Jays believed they stood to lose everything. They wanted independence from England but not through revolution, which could disrupt trade and their social station. Yet they were also merchants who resented any sort of government interference with trade. Since 1764 England's interference with colonial trade had led to new taxes. This practice enraged colonials, including the Jays, fomenting a resentment that provided the rationale for rebellion and John Jay's involvement in the American Revolution. ${ }^{35}$

Sarah Jay was another reason John became involved in the American Revolution. When Sarah Livingston and John Jay were married at Liberty Hall on April 28, 1774, John joined a politically outspoken Whig family. This was not an alliance likely to lessen John's animosity toward the crown of England and its repressive policies. Sarah Jay was better connected to the revolutionary movement than her husband. Another uncle, Philip Livingston, signed the Declaration of Independence. Robert Livingston, a cousin, was a member of the committee that oversaw the writing of the document. Her uncle Peter became president of the New York Provincial Congress and

\footnotetext{
${ }^{34}$ Birmingham, 17, 38-40.

${ }^{35}$ Ibid.
} 
her aunt Sarah, also known as Lady Stirling, was the wife of General William Alexander, Lord Stirling. Her own father, William Livingston, served fourteen consecutive terms as governor of New Jersey and signed the Constitution. ${ }^{36}$

When they married, John was twenty-eight and Sarah was only seventeen. Both profited from the match. John gained a strong tie to one of the most prominent, influential, and wealthiest families in New York, as well as a lovely, intelligent wife. Sarah won an educated husband whose intelligence and political consciousness matched her own. John Jay, patriot and barrister, was the perfect soul mate for a passionate young woman whose intellectual gifts, political insights, and devotion to the cause of American freedom needed only a conduit. ${ }^{37}$

Was the Jays' marriage a happy one? Birmingham writes that: “The answer is that it was probably as happy as that of any ambitious and successful couple who find themselves in the public spotlight and enjoying it. The only rule of marriage in the American eighteenth century was that a wife was to be absolutely obedient to her husband. ${ }^{\prime 38}$ It is true that a number of letters between John and Sarah were formal in content, but for the most part they demonstrated a partnership forged of emotions and understanding, not ambition, and although Sarah Jay frequently asked for the advice of her husband she often acted independently of him in her business and personal decisions. Birmingham's assumptions about marriage in the eighteenth century ignore the realities

\footnotetext{
${ }^{36}$ Booth, 215-16, 299-300.; Birmingham, 17.

${ }^{37}$ Birmingham, 17-23, 38, 41.Birmingham believes that John Jay married Sarah Livingston only to further his own goals and calculated ambitions and that Sarah was a domineering and controlling woman, which resulted in a marriage based on partnership and not love. I believe that this author misquoted and mistook the letters he cited, taking them only in part and completely ignoring a large number of letters that speak for their deep attachment to one another.; McCurdy, 24-26. Note: William Livingston's popularity did not decline when he left New York politics. He instead chose to leave after the DeLancey family seized control of the assembly, much to Livingston's disgust.

${ }^{38}$ Ibid, 56.
} 
of human relationships: arranged marriages often became loving relationships. The argument that men married money and connections, then loved their mistresses is no more proof that marriage was a loveless convenience in the eighteenth century any more than the argument that freedom to marry for love ensures it.

The beginning years of their marriage were marked by John's almost constant absence. Most of his time was spent attempting to reconcile the growing chasm between the colonies and the British crown as a representative to the First and Second Continental Congresses in Philadelphia. While John was away, Sarah remained with her family at Liberty Hall or at the Jay family home in Rye, New York. That state and New Jersey were among the hardest hit during the war. Not only were the Americans fighting the British, but also those Loyalists and rebels who were their neighbors. The young couple kept in constant contact with one another by letters throughout their separation and it is during this time that Sarah Jay emerged as a prolific writer. The flow of letters briefly stopped when she joined him in Philadelphia after John was elected president of the Continental Congress in $1779 .{ }^{39}$

Almost all of the letters between John and Sarah start with the formal salutation, "My dear Mr. Jay" or "My dear Sally”. Letters from John to Sarah were always signed "John Jay." While this degree of formality was typical of their exchanges in writing, it should not be mistaken for emotional reticence or distance. The phraseology and linguistic organization of the words may be formal, but the content of the passages

\footnotetext{
${ }^{39}$ McCurdy, 25.; Roberts, 162. John Jay was elected President of the Continental Congress on December 28, 1777.; Roberts, 106.
} 
express sentiment, care, worry, love, anxiety and a variety of other emotions that demonstrate the intensity and warmth of their relationship. ${ }^{40}$

Some historians, such as Stephen Birmingham, have suggested that the use of formal language in the letters between John and Sarah Jay indicate an emotionally distant, business-oriented marriage of convenience. ${ }^{41}$ He writes that John's letters to Sarah were "usually little more than lists of instructions concerning duties he wished her to perform," an interpretation which upon closer inspection seems highly unlikely. ${ }^{42}$

For Sarah was unhappy about her frequent separations from John, yet her letters suggest that she understood and accepted the reasons for his lengthy absences. Only upon one occasion did John have to remind her that she had "promised to be cheerfull and in Spirits." 43 Sarah did as she promised, for most of her letters are supportive and affectionate. She always attempted to remember John's maxim of "prepare for the worst and hope for the best." 44

The notable exception to her positive attitude occurred when she learned of John's election as president of the Continental Congress, not from her husband, but from a newspaper article. She was piqued that she did not hear directly from her husband of his promotion and in a letter vented her emotions to him. She wrote him of her perceived state of "widowhood" and said that she would "not have been Roman Matron enough to

\footnotetext{
${ }^{40}$ Freeman, 16-18.; John Jay to Sarah Livingston Jay, 14 November 1783, 150-51 and SLJ to JJ, 18 November 1783, 151 in Selected Letters. Almost all of the correspondence between John and Sarah Jay begin with "My dear Mr. Jay" or "My dear Sally". To see further evidence of this see SLJ to JJ, 18 November 1794, 242-43 and JJ to SLJ, 21 November 1794, 245 and SLJ to JJ, 5 December 1794, 245-46, in Selected Letters.

${ }^{41}$ Birmingham, 55-57.

42 Birmingham, 57.

43 JJ to SLJ, 23 May 1775, in Unpublished Papers, Vol. 1, 146.

${ }^{44}$ SLJ to JJ, 23-24 March 1777, in Unpublished Papers, Vol. 2, 379-81. Sarah Livingston Jay used the maxim of her husband, John, when over 1,200 British landed at Peekskill. With alarms constantly sounding, the young wife was frightened, yet did not want to appear so.
} 
give you so entirely to the public" had she known that she would learn of her husband's affairs through alternate means. ${ }^{45}$

Almost all of the letters from John to Sarah during this time are filled with inquiries about the state of her health, descriptions of his sadness at their separation, and petulant reminders for her to write more often. ${ }^{46}$ Jay worried when he did not receive a letter from his wife for he feared she was ill and did not write because she did not want to disclose her illness and worry him. Sarah Jay developed rheumatism at an early age and was often plagued by painful bouts of the disease. ${ }^{47}$ John missed his young wife and wrote "it is not good for man to be alone" and that "I find my present situation condemned, not only by my own feelings but by divine authority. ${ }^{, 48}$ It was a difficult, but necessary separation for a cause in which both believed. Although dedicated to his duty, John Jay made it clear that if he suspected his wife was "exposed to danger" he would come to her aid. ${ }^{49}$

These letters cast light on the relationship between the two and provide insights on John Jay's willingness to share political activities with his wife. He strongly believed that he could always "speak and write to you [Sarah] without that Circumspection which Prudence dictates in our common Converse with Mankind." ${ }^{\circ 0}$ He often wrote about the war and ending the "Tyrants Power". 51 Only upon one known occasion did John scold

\footnotetext{
${ }^{45}$ SLJ to JJ, 28 December 1778, in Unpublished Papers, Vol. 1, 516-17.

${ }^{46} \mathrm{JJ}$ to Catherine W. Livingston with Post Script from SLJ, 8 November 1776, in Unpublished Papers, Vol. 1, 320-21.; For examples of his letters in which he misses and inquires about the health of SLJ see JJ to SLJ, 24 May 1775, 146, and JJ to SLJ, 4 December 1775, 187, in Unpublished Papers, Vol. 1.; For gentle reminders when he has not received a recent letter from her and on the joy they bring him, JJ to SLJ, 29 July 1776, 305 and JJ to SLJ, 21 July 1775, 305, in Unpublished Papers, Vol. 1.

${ }^{47} \mathrm{JJ}$ to SLJ, 29 September 1775, in The Life of John Jay, Vol. 1, 167-68.

$48 \mathrm{JJ}$ to SLJ, 6 July 1777, in The Life of John Jay, Vol. 2, 13-14.

$49 \mathrm{JJ}$ to SLJ, 25 March 1777, in The Life of John Jay, Vol. 2, 11-12.

${ }^{50} \mathrm{JJ}$ to SLJ, 18 September 1775, in Unpublished Papers, Vol. 1, 166-67.

${ }^{51}$ JJ to SLJ, 21 July 1776, in Unpublished Papers, Vol. 1, 306.
} 
her in a letter, for arranging to travel to Elizabeth Town. At that same time John received an erroneous report that Elizabeth Town had fallen to the British and was frantic with concern. In response to his scolding, Sarah laughingly replied "The genteel manner in which you reprimand me for my imprudence (as you think it) charms me..." However, she quickly became serious and apologized for the worry she had caused him. ${ }^{52}$ John Jay missed his young wife and wrote that when the war was over they would "again join Hands and Hearts and continue our virtuous Connection forever., 53

Sarah's letters to her husband were often filled with concerned questions of health, queries on the current state of political affairs, and the gossip of the social world she moved within. John's letters brought comfort and solace to Sarah and she did not hesitate to express her unhappiness when she failed to receive a letter from him. While John would gently remind her to write more often, Sarah would chastise her delinquent husband subtly, but with more command: "Lord Chesterfield tells his son that women never frame any excuse arising from business, or any other circumstance to apologize for the silence of a correspondent, but always make a point of attributing it to neglect; how much his lordship was mistaken I leave to you to judge. ${ }^{, 54}$ It was a skillful criticism that reminded her husband of his duties to her. She would also seldom fail to give reminders, when the situation warranted, such as: "Permit me to remind you that there is a Post that takes letters from Morristown for Philadelphia and returns every week.. ${ }^{, 55}$

\footnotetext{
${ }^{52} \mathrm{JJ}$ to SLJ, 17 July 1776, in Unpublished Papers, Vol. 1, 294. For her response see SLJ to JJ, 27 June 1777, in Unpublished Papers, Vol. 1, 415.

${ }^{53} \mathrm{JJ}$ to SLJ, 21 July 1776, in Unpublished Papers, Vol. 1, 306.

${ }^{54}$ SLJ to JJ, 3 September 1777, in Unpublished Papers, Vol. 1, 442-43.; For another example of SLJ criticizing JJ for not writing, see SLJ to JJ, 28 December 1777, in Unpublished Papers, Vol. 1, 516-517.

${ }^{55}$ SLJ to JJ, 28-30 December 1778, in Unpublished Papers, Vol. 1, 516-517.
} 
Even though a large number of women during the revolution confined their political comments to private diaries and portfolios, the Livingston family was extremely close and communicative. Letters exchanged between numerous family relations, including the women of the family, were filled with frank political discussions which illustrate the development of political consciousness. These open exchanges brought ideas and speculations into a more public arena, although they were still confined within the domestic realm of the families. It is in these familial communications written prior to the Jay's mission to Spain in 1779, that Sarah's dry sense of humor and passionate patriotism emerged. ${ }^{56}$ In a letter Sarah wrote to her brother, Henry Brockholst Livingston, she remarks on being constantly shuffled about from town to town due to the ebb and flow of British occupation: "It is not a mortification to us who disclaim the tyranny of the King of England, that even the most interesting actions of our lives are controlled by his minions. ${ }^{, 57}$ It is important to note that she includes herself when she denounces the English throne in this letter, using the term "us" instead of "patriots"; she views herself not as existing on the periphery but as being at the heart of the revolution. These letters provide critical insights into Sarah's view of her role, for they demonstrate her enthusiastic participation in the political discourse of the era, even as she fulfilled her obligations in the domestic realm. Through her strong marital bond with John, Sarah was given license to speak her mind, allowing her to expand her intellect and political consciousness.

\footnotetext{
${ }^{56}$ Kerber, 76, 85.; Marylynn Salmon, "The Limits of Independence: 1760-1800," in No Small Courage: A History of Women in the United States, ed. Nancy F. Cott (Oxford: Oxford University Press, 2000), 84-85, 109-178.

${ }^{57}$ SLJ to Henry Brockholst Livingston, 18 August 1777, in Unpublished Papers, Vol. 1, 437-8. Henry Brockholst Livingston is more commonly referred to as simply "Brockholst" in correspondence.
} 
Contained within the letters to her family is the evidence of how Sarah was able to step beyond the passive role assigned to women of the eighteenth century and participate actively in the American Revolution from within the domestic realm. Much of her influence was subtle and expressed in private actions and correspondence, both appropriate during a time of war. John never chastised Sarah for her thoughts or comments; there is only encouragement and appreciation. Within this body of correspondence, Sarah's contributions are clearly valued. The tone and content of responses to Sarah's letters reveal that if she was not treated equally by society, she was treated as an intellectual equal by her own family. Sarah Livingston Jay developed a political consciousness and patriotism that continued to burgeon after she and her husband traveled abroad to Spain and France. 
Chapter Two: Sarah Livingston Jay 1779-1784, A Patriot Within the Bounds of Domesticity 
Sarah Livingston Jay worked for the cause of American independence. The revolution created an unusual position for women in that it allowed them to move into roles as politically conscious patriots. Through her sacrifices for the American Revolution and her experiences abroad Sarah Jay gained keen insights into the maledominated realm of power and privilege. This exposure, coupled with her own family's status, allowed her to create for herself and her family a secure position within society. Sarah Jay did not challenge the bounds of domesticity, but instead worked within them to gain power and prestige for herself and her husband, John. Sarah Jay's letters from 1779 to 1784 reflect an astute political mind. While abroad, she became a master of feminine pursuits. On her return to New York in 1784, she used her feminine knowledge of European courtly etiquette, fashion, and customs as a political tool. ${ }^{58}$

The Jays' European adventure began in 1779, when the couple sailed for Spain after John resigned the presidency of Congress to become Spanish ambassador. His mission was three pronged: first, to persuade Spain to join the alliance of France and America against England; second, to obtain from Spain unequivocal navigation rights for Americans on the Mississippi River; and third, to convince the Spanish monarch to loan a cash starved America over five million dollars with an interest rate of six percent or less. In return, Spain would receive Florida back when America and her allies won the war. ${ }^{59}$ Sarah Livingston Jay, then twenty-three, was the only wife of any American ambassador to accompany her husband abroad during the war. She left behind her home, her beloved family and her young son Peter Augustus, born on January 4, 1776. Peter divided his time between the Jay and Livingston households. The decision to leave her child and her

\footnotetext{
${ }^{58}$ Young, 181-218.

${ }^{59}$ Prince, The Papers of William Livingston, Vol. 3, 172.; Roberts, 162.
} 
family while war raged on her doorstep was courageous and heartbreaking. No wife, no matter how prominent her husband might be, was expected to leave children, home and hearth. No one would have faulted her for remaining behind rather than facing the unknown dangers that awaited her, and without knowing when —or if - she would ever see her son and her family again.

Her family, although surprised and saddened by Sarah's departure, expressed pride in her decision and in her unflagging support of her husband and the patriotic cause ${ }^{60}$ Her brother, William, Jr., wrote of her decision to accompany John to Spain as "...reflecting the brightest Honor on your Family and Country" $" 61$ and her mother, Susannah French Livingston wrote she understood it was Sarah's "duty" to accompany "her best Friend." ${ }^{62}$ Her father, William Livingston, warned her to "... suffer not the Gaities and Amusements of the world, and the particular Avocations of what is called high life." ${ }^{, 63}$ Her father may have provided different advice had he known that before her journey was over, Sarah would survive a disastrous voyage, desperate loneliness, the death of her baby, sickness, and difficult separations from her husband.

Sarah also dealt with a cruel betrayal that began within days of their departure by two men she and John trusted implicitly. The American delegation to Spain was comprised of John and Sarah Jay, Henry Brockholst Livingston, Sarah's brother, who served as John's private secretary, and William Carmichael, who was John's official

\footnotetext{
${ }^{60}$ Alsop, 192-93, 195.; McCurdy, 25.; Roberts, 163. Many wives refused to leave their family and friends to face the loneliness and dangers inherent in such a journey.; For evidence at the sorrow of her departure see William Livingston to SLJ, 7 October 1779, 675-76 and Susannah French Livingston to SLJ, October 9 1779, in Unpublished Papers, Vol. 1, 676.

${ }^{61}$ William Livingston, Jr. to SLJ, $16^{\text {th }}$ October 1779 , in Unpublished Papers, Vol. 1, 676-77.

${ }^{62}$ SFL to SLJ, 9 October 1779, in Unpublished Papers, Vol. 1, 676.

${ }^{63}$ WL to SLJ, 9 October 1779, in Unpublished Papers, Vol. 1, 675-76.
} 
secretary of legation. ${ }^{64}$ Sarah, with a lock of General George Washington's hair and his parting letter wishing her and the entire group "prosperous gales, unruffled Sea, and every thing pleasing and desirable," set sail aboard the Confederacy on October 20, $1779 .{ }^{65}$

George Washington's parting words were well meant, but did not prove prophetic. The journey was disastrous. There was little wind for the first five days out of port, slowing the Confederacy to a bare crawl. Then in the early morning hours of November 7, 1779, the ship was caught in a terrible gale as it moved through the North Atlantic into the Gulf Stream. ${ }^{66}$ The gale tore the ship apart, leaving it at the mercy of the waves. The "bow-sprit, fore-mast, main-mast, and missen-mast" were destroyed, leaving the ship defenseless and barely able to make its way. Several crew-members were seriously injured in the gale, one later dying from his injuries. Sarah was courageous in the face of possible death, writing that she "gave fear to the winds and cheerfully resigned myself to the dispensations of the Almighty." The next morning they were battered by high winds and the rudder gave way to the tremendous stress placed on it. ${ }^{67}$

Captain Seth Harding of the Confederacy was faced with two choices: continue on to Cadiz at great risk to the ship and all aboard or sail to Martinique for repairs. Harding favored Martinique, a scant two hundred miles away. With the rudder and several masts jury-rigged, Martinique was the safest obtainable destination. John Jay deferred to the opinion of the seasoned Captain, which infuriated another passenger, the French minister to America, Conrad Alexandre Gerard. Gerard was desperate to return

\footnotetext{
${ }^{64}$ Roberts, 192-93.

${ }^{65}$ George Washington to JJ, 7 October 1779, in Unpublished Papers, Vol. 1, 656.

${ }^{66}$ Alsop, 197-98.; HBL to SFL, 25 October 1779, in Unpublished Papers, Vol. 1, 678-79.

${ }^{67}$ SLJ to SFL, 12-26 December 1779, in Unpublished Papers, Vol. 1, 680-84.
} 
home. While in America he became too intimately involved in the factional disputes between various Congressmen. The French government was displeased with his actions and replaced him with Chevalier de la Luzerne. Gerard, hoping to clear his name and deal with several time sensitive business deals awaiting him in France, demanded the Captain sail directly to Cadiz. John's secretary, Carmichael, who should have deferred to Jay, surprisingly supported Gerard. Carmichael's apparent betrayal distressed both John Jay and his wife. ${ }^{68}$ The animosity created between John Jay and William Carmichael increased throughout the journey and was transformed into full-blown loathing before the mission to Spain was completed.

As the ship made its slow progress to Martinique, Sarah Jay made use of her time, for she was not plagued by seasickness or impaired by shipboard conditions. Although there was no Spanish tutor available on the Confederacy, she worked diligently at refining her French. If the need arose to go to France, she wanted to be able to present herself at the Court of Versailles without embarrassment stemming from ignorance of the language. To pass the time and perfect their French, Sarah Jay and several others refused to speak anything but French while in their cabin. She worked so hard that her brother, Brockholst, commented she was “...a very apt Scholar..." and noted that "Seriously, I believe she will soon speak French, and with fluency." ${ }^{\circ 9}$

Although the journey to Martinique was uncomfortable and terrifying, Sarah never had "a moment's complaint," a small miracle considering that she was then pregnant with her second child. ${ }^{70}$ In letters to her family young Sarah Jay framed the

\footnotetext{
${ }^{68}$ Alsop, 192.; Monaghan, 125-27.; SLJ to SFL, 12-26 December 1779, in Unpublished Papers, Vol. 1, 680-84.

${ }^{69}$ HBL to SFL, 25 October 1779, in Unpublished Papers, Vol. 1, 678-680.

${ }^{70}$ Ibid.; Norton, 77.
} 
terrifying events of the voyage more like an adventure story than a near calamity. She urged those at home not to worry for her. She never mentioned her pregnancy in her letters because the mail could be opened and read by anyone involved in its delivery. Nor did Sarah mention the unpleasant affair with Gerard and Carmichael. She even attempted to heal the breach between John and Gerard and liven up the somber atmosphere of the ship by throwing a party for Madame Gerard on December 7 to celebrate the older woman's birthday. The affair was complete with decorations, breakfast, cards, chess, and dancing. By the application of her domestic skills as a form of mediation, Sarah Jay's shipboard event did much to assuage Gerard's ego. ${ }^{71}$

On December 18, 1779 the beleaguered Confederacy finally made port in St. Pierre, Martinique. Sarah Jay was enchanted by Martinique and wrote that the island was the most "verdant, romantic country I ever beheld" and that "the pleasure we received there would have amply compensated for the inconveniencies we sustained on our passage. ${ }^{, 72}$ Her favorable report probably had a great deal to do with their accommodations while on the island, for they stayed in William Bingham's fine home. Bingham was a congressional representative to the island. ${ }^{73}$ One experience Sarah Jay enjoyed while on the French-held island was a review of the local garrison, for “...in viewing such fine Troops, [she] recognized the friends of American Liberty." ${ }^{, 74}$

Her only complaint of their stay upon the island was that it was so short, for the American party set out once again on December 28, 1779 upon the French frigate Aurora, commanded by the Marquis de la Flotte. Just before reaching Cadiz Bay the

\footnotetext{
${ }^{71}$ SLJ to SFL, 12-26 of December 1779, in Unpublished Papers, Vol. 1, 680-84.

${ }^{72}$ McCurdy, 25.; SLJ to SFL, 12-26 December 1779, in Unpublished Papers, Vol. 1, 680-84.

${ }^{73}$ SLJ to SFL, 12-26 December 1779, in Unpublished Papers, Vol. 1, 680-84.; SLJ to Peter Jay, 9 January 1780, in Unpublished Papers, Vol. 1, 687-89

${ }^{74}$ SLJ to PJ, 9 January 1780, in Unpublished Papers, Vol. 1, 687-89.
} 
American contingent experienced yet another frightening occurrence when the Aurora was chased by an English frigate. While the crew was preparing for a naval engagement, Sarah Jay "went upon deck and staid there till the chase was over." Aurora, the Marquis was able to outrun his English pursuers and bring the Aurora safely into the harbor. The alarming experiences of the voyage made Sarah Jay all the more aware of the importance of the mission to Spain. Jay called King George III a "once haughty foe" who now "finds himself depriv'd of [a] great part of his Empire, dignity \& the confidence of many of his subjects. ${ }^{, 76}$ Mrs. Jay was dedicated to the cause of independence.

The voyage also reinforced for Sarah her pride in the rights Americans enjoyed. In one of her countless letters home, perhaps concerned that her mother and sister would doubt her patriotism or dedication to the newly formed country because of her long absence and many favorable remarks of Martinique, Sarah wrote:

Do you think, girls, that distance diminishes my affection for Americans, or my concern for their interest? Oh! No; it encreases my attachment even to enthusiasm. Where is the country (Switzerland excepted) where Justice is so impartially administered, industry encouraged, health and Smiling plenty so bounteous to all as in our much favored Country? And are not those blessings each of them resulting from, or matures by freedom, worth contending for?...But... What have I to do with politicks? Am I not myself a woman, and writing to Ladies? ${ }^{77}$

Despite her disclaimer, Sarah Jay was an ardent revolutionary whose conviction was based on sound political philosophy. In the letter she recognizes the necessity of fighting for traditional rights and privileges, which she believed could only be found in America and Switzerland. Even as she expounds on these themes of independence, she

\footnotetext{
${ }^{75}$ SLJ to CWL and SFL, 4 March 1780, in The Papers of William Livingston, Vol. 3, 285-288.

${ }^{76}$ SLJ to WL, 31 January 1782, in Selected Letters, 117.

${ }^{77}$ SLJ to CWL and SFL, in Unpublished Papers, Vol. 1, 692-93.
} 
apologizes for mentioning them. Sarah Jay understands that to comment openly about politics was stepping outside the bounds set for women in the eighteenth century.

In another letter to her father, Governor William Livingston, Mrs. Jay wrote of Americans "...the sun shines not on a more worthy people, even in their errors virtue is conspicuous..."78 This quotation demonstrates not only her loyalty, but also an ethnocentric belief that Americans were pristine in their societal and political mores, that there was an innate or natural quality in Americans that inclined them to freedom and justice. She went on to write, “...certain I am that victory will one day give to the Americans that liberty they have had the virtue to defend."79 This is a constant theme in Sarah's letters, one that reinforces her earlier letter to her mother and sister. She believed the cause of independence to be virtuous and moral, both concerns of the domestic realm. After spending five weeks in Cadiz the American party, during the second week in March, set out over land for Madrid, the capital of Spain. During the sojourn in Cadiz, Sarah suffered from a bronchial infection that began on the Aurora. The discomforts of the journey that began on sea continued on their cross-country sojourn. Spain in the late eighteenth century held few comforts for cross-country travelers, no matter how distinguished. Sarah's party carried all their necessities with them, including beds, mattresses, food, guns, sheets, and eating utensils. Once again the journey was arduous and the expedition to Madrid was filled with trials and unpleasantness. Among these were the small wooden crosses left on the highway in each place where a traveler was found murdered. ${ }^{80}$

\footnotetext{
${ }_{78}^{78}$ SLJ to WL, 14 March 1781, in Unpublished Papers, Vol. 2, 177-80.

${ }^{79}$ Ibid.

${ }^{80}$ SLJ to SFL, 28 August 1780, in Unpublished Papers, Vol. 1, 704-09.
} 
When lucky enough to find any accommodations for the night, the Jay party spent the first part of the evening removing moldy mattresses riddled with lice and vermin from their cramped sleeping spaces, then sweeping their sleeping quarters clear of accumulated dirt and grime. ${ }^{81}$ Sarah Jay bore the disagreeable journey well and without complaint, despite the added hardships of her pregnancy, although "her surprise was not less than if silence had been observed on that subject" ${ }^{\prime 22}$ in regard to the roughness of the overland trek. These were not typical conditions for wealthy urban New Yorkers.

After six harrowing months at sea and on the back roads of Spain, the American ambassadorial party finally reached Madrid. Sarah Jay had already survived many harrowing experiences for the patriot cause, but kept silent on the discomforts stemming from her pregnancy and the arduous journey. Sarah Jay well understood that the challenges of establishing themselves with the Spanish court demanded as few distractions as possible; she voiced no complaint. Autonomy from England was a tenuous prize at best, demanding every ounce of energy and sacrifice to ensure that the fragile welcome she and John anticipated would not crumble under the weight of diplomatic technicalities or the realities of European politics.

Upon reaching Madrid on April 4, 1780 the American delegation faced numerous problems. John Jay was not received at the Spanish court as an official ambassador from America because Spain, as a colonial power, did not recognize America's independence from Britain. This rendered his diplomatic credentials and mission an exercise in futility. To complicate matters further, the Spanish monarch was rarely in the capital city, moving the court at his whim to royal palaces that were scattered throughout the Spanish

\footnotetext{
${ }^{81}$ SLJ to SFL, 28 August 1780, in Unpublished Papers, Vol. 1, 709-712.

${ }^{82}$ Ibid.
} 
countryside. John Jay was often forced to pack his bags at the last moment, and trail after the royal entourage, leaving his very pregnant wife alone in a foreign capital.

Sarah Jay bore the burden of isolation in a foreign land with grace and dignity, even though she found herself extremely lonely at times because she did not speak the language. She mentioned in several letters home that she resented the Spanish monarch's habit of constant relocation, which forced her husband to leave her alone. It was impossible for her to accompany him. Spain's reluctance to grant the United States of America diplomatic recognition prevented Sarah from socializing with the wives of other foreign diplomats. Sarah and John Jay were guests without status, and as such, were precluded from the traditional welcomes accorded foreign diplomats. To her sister, Catharine W. Livingston, Sarah wrote, “...I suppose your Ladyship is impatient for a word of Madrid; and a word may very well suffice." She wrote there were few amusements in Madrid due to a drought and the high costs of everyday items. ${ }^{83}$

Although there were few public entertainments open to Jay, she took great pleasure in the "...very beautiful walks and publick gardens" ${ }^{84}$ In her letters home she often mentioned the "handsome fountains and excellent roads" with trees that "adorned the roads and walks." ${ }^{85}$ She delighted in the magnificent sculptures that seemed to fill the city. The equestrian statues of Emperor Charles V that depicted him in three different

\footnotetext{
${ }^{83}$ Alsop, 208, 213. There were five principle palaces in Spain: the main palace in Madrid which the King rarely visited, El Prado located about ten miles from Madrid, Aranjuez that was almost thirty miles away, Escorial was located far to the North, and the palace of San Ildefonso that lay nestled in the mountains near Segovia.; SLJ to SFL, 13 May 1780, in Unpublished Papers, Vol. 1, 694-96.; SLJ to CWL, 14 May 1780, in Unpublished Papers, Vol. 1, 696-98.; Jay, Vol. 2, 77-78. This discusses the financial situations of the Jay's and the lack of funding provided by Congress for the mission.

${ }^{84}$ SLJ to CWL, 14 May, 1780, in Unpublished Papers, Vol. 1, 696-98.

${ }^{85}$ SLJ to WL, 14 March 1781, in Unpublished Papers, Vol. 2, 177-80.
} 
stages throughout his life, captured her imagination. ${ }^{86}$ Another set of sculptures that intrigued her were found in the royal gardens of the San Ildefonso Palace. Here were the "whole...mytholigy \& the metamorphoses of Ovid represented...by figures vastly larger than the life. ${ }^{" 87}$ Sarah Jay, unhappy without her husband, often sought beauty and inspiration where she could. The gardens, beautiful and tranquil, stood in stark contrast to the withered, sweltering landscape beyond them.

Despite her isolation Sarah remained strong and devoted to the patriot cause as did most of her family. She was reluctant to cause her relations to worry and carefully avoided references in her letters home that might have revealed the full extent of her frustrations or fears. Sarah Jay was lonely and in letters home she often referred to the number of letters she received from family members. She found the separation from her family difficult and tried to express how important their letters were to her. She feared for the safety of her family in a war that was increasingly violent. She voiced her love for her friends and family, but was dissatisfied with her efforts. She wrote, "I...wish to describe the sentiments of my heart...but the letters convey so faint an image of them that I can only trace a distant resemblance". 88

Sarah Jay wrote often of the war, specifically about the soldiers involved in the struggle, her letters always betraying her pride in and sympathy for them. Sarah viewed herself as intrinsically linked to the "noble efforts" of the war, not as a separate, nonparticipating entity because of her gender. She never questioned the necessity of the war and regularly requested that her relatives include "in every letter some of their

\footnotetext{
${ }^{86}$ SLJ to WL, 14 March 1781, in Unpublished Papers, Vol. 2, 177-80. The three depictions of Charles V were of him with the saddle and clothes he wore as the Conqueror of Tunis, as crowned King of the Romans, and as the King of Spain.

${ }^{87}$ SLJ to Mary White Morris, 17 September 1781, in Selected Letters, 115.

${ }^{88}$ SLJ to CWL, 1 December 1780, in Unpublished Papers, Vol. 1, 170-72.
} 
Actions" and that "nothing delights me more than the praises of my Countrymen." yearned for peace so the soldiers could "long enjoy the liberty for which they have so nobly struggled" and hoped that God would eventually grant them "liberty and crown their council and their arms with success." ${ }^{, 90}$ Sarah Jay never apologized for her patriotic letters. Her patriotism was voiced during a time of war and within private correspondence, so her political statements did not cross the bounds of propriety.

When her sister, Catharine, sent her a broadside entitled "The Sentiments of an American Woman." Sarah wrote it was an "...agreeable and honorable a representation of my lovely country-women. I am quite charmed with them, and indeed everything truly American." ${ }^{91}$ In 1780, when The Sentiments of an American Woman was first published, it contained more overt revolutionary and political ideas than that in the Ladies of Edenton's petition, yet it was more readily accepted by society. ${ }^{92}$ Sarah Jay was aware of the shift in what was considered proper feminine pursuits and took full advantage of the shifting paradigms.

Several months after Sarah Jay expounded the virtues of her female co-patriots she gave birth to Susan, who was welcomed to the world on July 9, 1780, without the female support of Sarah's family that was typical of the late eighteenth century. John Jay was ecstatic at the easy birth. There was no medical trauma, and the birth was not overly difficult; both mother and daughter appeared to be in perfect health. Sarah attributed this to the climate, which she claimed was favorable to pregnant women. The proud father

\footnotetext{
${ }^{89}$ SLJ to SFL, 28 August 1780, in Unpublished Papers, Vol. 1, ,704-09.

${ }^{90}$ SLJ to CWL, 14 May 1780, in Unpublished Papers, Vol. 1, 694-96.

${ }^{91} \mathrm{SLJ}$ to CWL, 1 December 1780, in Unpublished Papers, Vol. 1, 170-72.

${ }^{92}$ Earle, 253-54.; Kerber, 167.
} 
could not wait to include mention of the birth in his letters to family and friends, including William Livingston, Benjamin Franklin, and John Adams. ${ }^{93}$

The birth of a child meant a relief from the loneliness and isolation Mrs. Jay had experienced in a society devoid of "intimate friends" and in a country whose "customs, language, and religion are the very reverse of our own"94. She was delighted with Susan and said her birth answered "every wish of my heart ${ }^{95}$ ". She looked forward to nurturing her second child even as she constantly inquired of her son Peter in her many letters home. Sarah Jay was interested in every aspect of her son's growth and development, and wanted to be kept informed of every educational, social and personal event. She wrote to discover if there was anything he needed for his studies that was not obtainable in war-torn America that she could procure abroad. When the Livingstons were forced by the British to retreat from their home and Sarah learned they were all safe, she wanted to know how her son acted during the flight. Sarah was a caring mother who regretted leaving her son behind, despite its necessity. ${ }^{96}$

The happy interim did not last, for Susan developed a fever and died on August 4, 1780, scarcely a month after her birth. Sarah Jay was devastated by the death of her daughter, which was compounded by the lack of family support, isolation in Madrid, and the constant absences of her husband. Still, she carried on: she barely mentioned her

\footnotetext{
${ }^{93} \mathrm{JJ}$ to Benjamin Franklin, 17 July 1780, in Unpublished Papers, Vol. 1, 793-95.; JJ to John Adams, 17 July 1780, in Unpublished Papers, Vol. 1, 792-93.; JJ to WL, 14 July 1780, in Unpublished Papers, Vol. 1, 703-04.; It should be noted that Norton, in Liberty's Daughter, mentions the lack of attachment that parents held for their children upon their birth due to the high mortality rates of the babes in the first few months. Although John Jay does refer to Susan as the "little Stranger" upon her birth, it appears that this was due more to a debate occurring in regard to her name, rather than any parental detachment.; SLJ to SFL, 28 August 1780, in Unpublished Papers, Vol. 1, 709-712.

${ }^{94}$ SLJ to SFL, 28 August 1780, in Unpublished Papers, Vol. 1, 709-712.

${ }^{95}$ Ibid.

${ }^{96}$ SLJ to WL, 18 July 1783, in Unpublished Papers, Vol. 2, 610-12.; SFL to SLJ, 27 May 1781, in Unpublished Papers, Vol. 2, 185-87.; SLJ to SFL, 13 May 1780, in Unpublished Papers, Vol. 1, 694-96.; SLJ to CWL, 1 December 1780, in Unpublished Papers, Vol. 2, 170-72.
} 
despair, except in one heartbreaking letter to her mother, in which she even apologizes for her remorse, understanding that her mother had "wept on similar occasions." Jay combined strength and purpose and direction with a remarkable degree of empathy.

Sarah had little family support from her brother, Brockholst, who joined the mission to Spain to “...perfect himself in two languages, gain a knowledge of mankind, form useful connections, and...make... a proficiency in the study of Law." "98 But Brockholst grew bored with the ordinary tasks assigned to him by John Jay. The glamorous court life he expected in Spain never materialized. As he became more and more disillusioned, he voiced his frustrations to William Carmichael. ${ }^{99}$ The resultant animosity directed to John Jay following the death of Susan, added to the stress and grief of husband and wife.

Brockholst and John Jay quarreled frequently about the slightest issues, with Sarah Jay often acting as mediator. One major incident occurred during a formal dinner in front of several foreign guests when Brockholst commented that the newly formed American Congress was nothing but a bunch of drunkards, worse than any monarchy. Sarah Jay tried to cover the undiplomatic remarks when she said "Oh Congress are like other men $\&$ the custom of getting drunk after dinner is general."100

Sarah thought Brockholt's statements against Congress were "imprudent" to make, especially in front of foreign guests when he was a "servant of that Assembly."101 Sarah's gentle rebuke of her brother's crude remarks was a comment that may be construed as outside the realm of behavior permitted to women of the time. Despite the

\footnotetext{
97 Ibid.

${ }^{98}$ SLJ to WL, 24 June 1781, in Unpublished Papers, Vol.2, 188-94.

${ }^{99}$ Alsop, 222.

${ }^{100}$ SLJ to WL, 24 June 1781, in The Papers of William Livingston, Vol. 4, 225-233.

101 Ibid.
} 
fact that she criticized a male family member to whom society dictated that she technically owed deference, I do not believe she crossed the line of propriety. He was, after all, her younger brother and sibling rivalry often resulted in harsh remarks.

Subsequent occurrences between Brockholst and John are recorded in a letter from Sarah Jay to her father, William Livingston. It occurred when John Jay gently reminded Brockholst that Congress should be spared the censure of Americans. In response Brockholst called the members of Congress "great rascals." ${ }^{102}$ Sarah Jay refused to back down in defense of the country she loved so much and replied "that in America no ill could arise from scrutinizing their conduct, but that here as the independence of America had not been publicly acknowledged, we should be careful not to lessen the respectability of the representatives of our Country." ${ }^{, 103}$ Her political awareness and shrewd political instincts infuriated Brockholst. Brockholst departed in anger for William Carmichael's house, where he could freely say what he wished about Congress. When Brockholst finally returned to the Jay home, he said he would rather return to America than be treated like a "slave."104

The slight against the Jays was scurrilous, for the Jays had tried to make Brockholst comfortable in Spain, paying him a tidy allowance. They were also discreet about his late night cavorting, which included drinking, occasional gambling, and a number of masquerades. The Jays blamed Brockholst's errant behavior on Carmichael who was jealous of John's diplomatic abilities and position; by the end of the Spanish debacle John Jay and William Carmichael came to despise one another so much that Jay concluded Carmichael was a spy. Sarah Jay detested him only slightly less and wrote

\footnotetext{
102 Ibid.

${ }^{103}$ Ibid.

${ }^{104}$ Ibid.
} 
“Had I been in Mr. Jay's place I never could have observ'd such moderation \& civility." ${ }^{, 105}$ This is a remarkable statement from a woman who was generous in her personal assessments and willing to subordinate her own feelings for the greater political good.

Brockholst returned shortly thereafter to America, but Sarah Jay refused to let the matter rest. She believed that once Brockholst arrived in America he would attempt to sully John's good name. Anticipating Brockholst's slander, Sarah Jay wrote to her father, detailing everything that had occurred with Brockholst and Carmichael. The letter was delivered to Sarah's sister, Catharine Livingston, with an injunction to send it on to their father should Brockholst give his version of events in Spain. Sarah was a logical, insightful and well-prepared opponent to any who threatened her husband. Ironically, Brockholst never mentioned the incidents to his father. ${ }^{106}$

Sarah Jay's defense of Congress and of her husband's position demonstrated a loyalty to her husband she would not relinquish even to her brother. Some contemporaries believed Sarah Jay was the dominant partner in her marriage, to the point where the Spaniard Diego de Gardoqui wrote "This woman, whom he loves blindly, dominates him and nothing is done without her consent, so that her opinion prevails." Even if she were the dominant figure in the marriage, she did not step out of her assigned role.

She was a determined woman who knew exactly what she wanted and how to get it, but always within a core of integrity that looked to the good, and not to the selfish or self-serving. Although Sarah Jay was furious about the situation with Brockholst, she

\footnotetext{
105 Ibid.

${ }^{106}$ SLJ to WL, 24 June 1781, in The Papers of William Livingston, Vol. 4, 225-233.

${ }^{107}$ Roberts, 165 .
} 
related the information only to her sister Catharine with instructions to make it known to her father only if Brockholst spoke of it first. Sarah Jay used discretion in disseminating the information, for she understood the problems that could arise from tarnishing Brockholst, who was the apple of her father's eye. She also did not want to tarnish the strong relationship between William Livingston and John Jay. By writing to her sister Sarah once again remained within the boundaries of society. She set a safe-guard should circumstances warrant her breaking her silence. ${ }^{108}$

Despite the Jays' best efforts, their diplomatic mission to Spain was a complete disaster. Spain never recognized American independence. John could not convince the Spanish monarch to agree to any part of the terms America sought. At the urging of the Jay's longtime friend, Benjamin Franklin, the couple decided to declare the Spanish mission a complete loss and join Franklin in Paris. Sarah Livingston Jay had already dealt with a frightening sea and overland trek, isolation and loneliness in a foreign land, the death of a child, a family estrangement, and several illnesses. She must have wondered what awaited her in yet another European country, and yet the idea of leaving Spain behind for the French court must have held some appeal.

Leaving Carmichael behind to carry on as temporary charge d'affaires in Madrid, Sarah and John Jay set out for Paris, France, taking with them their few possessions, and a new baby, Maria Jay, born on February 20, 1782. Once again their pace of travel was slow and Sarah fell ill with a fever and ague and the baby, Maria, developed "Hooping

\footnotetext{
${ }^{108}$ Ibid.
} 
Cough." Despite Sarah being too sick to nurse the infant, both recovered from their illnesses. $^{109}$

The couple arrived in France on June 22, 1782, settling in at the Hotel de Chine and John Jay immediately presented his credentials at the Palais Royal. Sarah Jay was enchanted with the young Queen, Marie Antoinette, and wrote that there were "many traits in her character worthy of imitation, even by Republicans."110 Besides commenting on her immaculate fashion sense, Sarah Jay was impressed with the queen's insistence on educating her daughter.

The Jays' stay in France proved to be eminently more successful than the Spanish debacle. It began with the French court's diplomatic recognition of John Jay as an official representative of America. Sarah was fluent in French, enabling her to converse freely. She had another child to care for, which helped to dull the ache of Susan's death and the constant separations from her husband. Mrs. Jay enjoyed the "gaiety and industry" of the inhabitants and how nearly everyone was of a cheerful disposition. ${ }^{111}$ The couple summered at Benjamin Franklin's house in Passy, where the Jays' second surviving daughter, Nancy Jay, was born August $13,1783 .^{112}$

While in France the Jays were part of diplomatic society and constantly besieged with invitations and frequent visits from scores of friends. They often visited with Benjamin Franklin and the Marquis de Lafayette. Sarah Jay also enjoyed the hospitality of the Comte d'Estaing, the Comte de Rochambeau, the Comte de Sarsfield, and Chevalier de Chastellux. There was also a significant American presence in Paris, a

\footnotetext{
${ }^{109}$ SLJ to CWL, 14 August 1782, in Unpublished Papers, Vol.2, 460-62.; Morris, Unpublished Papers, Vol. 2, 770 .

${ }^{110}$ Birmingham, 52.

${ }^{111}$ SLJ to SFL, 28, August 1782, in Unpublished Papers, Vol. 2, 464-66.

${ }^{112}$ Alsop, 226.; Birmingham, 52-55.; Freeman, in Selected Letters, 22.; Roberts, 171.
} 
welcome change from the isolation Sarah Jay experienced in Spain. She was able to enjoy the sound of American English and spend time with fellow Americans who shared a common frame of reference. The vibrant social engagements set against the backdrop of the French monarchy was a welcome change from the Jays' previous role as social pariahs in Spain. ${ }^{113}$

Sarah Jay took full advantage of the cultural opportunities open to her as the wife of a recognized diplomat. Her time in France, for the most part, was passed in an agreeable manner. She attended a number of plays where she often saw Queen Marie Antoinette. She also met a number of well-known intellectual men, including the social reformer Francois de La Rochefoucald, the controversial metaphysicist Franz Anton Mesmer, the chemist Antoine-Laurent Lavoisier, and the mathematician Adrien Legendre. These experiences broadened and expanded Sarah Jay's perceptions of the world. She concentrated on the roles assigned to her gender and learned the mannerisms of the sophisticated and elegant French, courtly etiquette, and cultural standards, including fashion and haute cuisine, all of which aided her when she returned to America. She also learned how to expand her role as wife and socialite through opulent entertaining and educating her daughters. It was a new way to perceive an old role, in which she excelled. ${ }^{114}$

During this era, French culture set the world's standard and French fashions ruled the world. Sarah took full advantage of the latest styles and dressed elegantly, so much so that the twenty-six year old Sarah Jay was often mistaken for the twenty-eight year old

\footnotetext{
${ }^{113}$ Morris, in Unpublished Papers, Vol. 2, 455-56.

${ }^{114}$ Birmingham, 51-52.; Mrs. <?> Ellet, Queens of American Society (New York: Charles Scribner \& Company, 1867), 65. This section contains quotes from letters written by Sarah Jay.; SLJ to JJ, 17 January 1783, in Unpublished Papers, Vol. 2, 596-97.
} 
Queen of France, Marie Antoinette. One evening when Sarah arrived at a Paris theater with the Marquis and Marquise de Lafayette, the entire audience rose upon her entrance, mistaking her for the Queen. ${ }^{115}$

Ladies' fashion in France changed almost weekly and represented the capriciousness of the French. Many of the most prominent women of France, including Queen Marie Antoinette and her close friends the Comtesse Diane de Polignac and Marquise de Vaudrienne, set the tone for the various fashionable fads. Clothes, accessories, hairstyles, and particularly shoes were visible symbols of power and wealth in late eighteenth-century France. Women, in particular, found that clothing provided an avenue for gaining power. Milliners and dressmakers were in great demand and only the most elite could afford to purchase the expensive creations of lace and silk that could easily be viewed as works of art. There were "so great a variety" of styles, materials, and colors used that Sarah Jay found it "impossible to describe them". ${ }^{116}$ Sarah Jay took full advantage of the connections she established in France and obtained many brilliant and fashionable creations. Many of the dresses and accessories she purchased were forwarded home to America for her use when she returned. ${ }^{117}$

John Jay was regularly absent from home while negotiating the critical Treaty of Paris that would officially end the American Revolution when it was signed in 1783. Sarah Jay was left to care for their two young daughters, oversee the household, and entertain extensively, as was expected of one of her social station. Maria, and later Nancy, were a delight to the young mother. Maria worried both John and Sarah for a

\footnotetext{
115 Birmingham, 52, 53.

${ }_{116}^{116}$ SLJ to MWM, 14 November 1782, in Unpublished Papers, Vol. 2, 475-76.

117 Alice De Lancey Izard to SLJ, 2 July 1782 in Unpublished Papers, Vol. 2, 457.; Ellet, 60.; SLJ to MWM, 14 November 1782, in Unpublished Papers, Vol. 2, 475-76.
} 
time, as she refused to speak. Sarah believed her lack of linguistic skills could be attributed to hearing so many different languages at once. Maria Jay did eventually learn to speak, but this period was a trying one for Sarah, who felt she was somehow failing Maria and missing an important step in her daughter's development. ${ }^{118}$

Despite her republican ideals, Sarah Jay was a creature of her times and governed by contemporary mores. This was illustrated in her treatment of her personal maid, Abbe, who became jealous of the Jay children's nurse, Louisson, and ran away. This was a breach of French law. Offered a job by an English washerwoman, Abbe seized the opportunity. As would any upper class Frenchwoman or American, Sarah Jay contacted the police. Abbe was taken into custody and imprisoned, whereupon Sarah Jay sent William Temple Franklin, Benjamin Franklin's grandson, and Peter Jay Munro to speak with her and ask her to come home. She refused to return, not wanting to face Louisson. ${ }^{119}$

Sarah Jay did not initially inform John of the situation because she did not want to alarm him and she felt fully capable of handling the matter herself. Eventually she wrote to John, but only after William Temple Franklin informed him of Abbe's defiant behavior. Servants were expected to obey their masters and mistresses. Flight was a serious offense. Sarah and Franklin decided to leave Abbe in the house of confinement for fifteen to twenty days, in the hopes she would see reason. ${ }^{120}$ Peter Jay continued to

\footnotetext{
${ }^{118}$ SLJ to WL, 18 July 1783, in Unpublished Papers, Vol. 2, 610-12.; JJ to SLJ, 20 October 1783, in Unpublished Papers, Vol. 2, 624-25.; SLJ to JJ, 6 November 1783, in Unpublished Papers, Vol. 2, 63436.; JJ to SLJ, 23 November 1783, in Unpublished Papers, Vol. 2, 647.; SLJ to JJ, 30 November 1783, in Unpublished Papers, Vol. 2, 655-56.

${ }^{119}$ Freeman, in Selected Letters, 147.

${ }^{120}$ SLJ to JJ, 6 November 1783, in Selected Letters, 147-48.; Peter Jay Munro to JJ, 12 November 1783, in Selected Letters, 148-49.
} 
visit her, but he wrote that the visits "Increased her Ideas of importance and the last time I saw her she was more sullen than at either of the former."121

Sarah Jay was concerned Abbe might develop an illness if she remained in confinement, but John thought she should be left without "wine and improper company" until she agreed to return to the Jay household. ${ }^{122}$ Within two weeks Abbe relented and begged to return to Jay's employ. When Abbe returned she was extremely ill. Sarah Jay held no harsh feelings towards Abbe for her conduct and succored her during her illness. Whether or not Abbe resented her treatment is unknown. One can speculate that Abbe was angry and bitter, but not for long, for despite Sarah's best efforts Abbe died shortly thereafter. ${ }^{123}$

The couple was saddened by Abbe's death, but their grief was overshadowed by the momentous event that came shortly thereafter: the signing of the preliminary articles of peace. When the preliminary articles of peace with England were signed in January of 1783, Sarah Jay called her husband a "deliverer of our country." 124 Benjamin Franklin, John Jay, and John Adams signed the definitive Treaty of Paris on September third. She was proud of her husband's accomplishments and ecstatic at the prospect of finally returning home to her beloved America and to her family and son, although she was "much pleased with France". ${ }^{125}$ Sarah Jay planned a celebratory ball for the successful outcome of the American Revolution to express her happiness at her country's success at gaining independence from Great Britain. The ball held in the summer of 1783, but

\footnotetext{
${ }^{121}$ PJM to JJ, 12 November 1783, in Selected Letters, 148-49.

122 JJ to SLJ, 23 November 1783, in Selected Letters, 153.

${ }^{123}$ SLJ to JJ, 7 December 1783, 159 and SLJ to JJ, 11 December 1783, 161-62 and JJ to SLJ, 26 December 1783, 162 in Selected Letters.

${ }^{124}$ McCurdy, 25.; SLJ to JJ, 21 January 1783, in Columbia Online.

${ }^{125}$ SLJ to SFL, 28 August 1782, in Unpublished Papers, Vol. 2, 464-66.
} 
Sarah was not able to attend, having shortly before given birth to Nancy. ${ }^{126}$ In her stead she sent a toast to be read by her husband:

\section{"A Toast to America and Her Friends"}

1. The United States of America, may they be perpetual

2. The Congress

3. The King and Nation of France

4. General Washington and the American Army

5. The United Netherlands and all other free States in the world

6. His Catholic Majesty and all other Princes and Powers who have manifested Friendship to America

7. The Memory of the Patriots who have fallen for their Country-May kindness be shown to the Widows and Children

8. The French Officers and Army who served in America

9. Gratitude to our Friends and Moderation to our Enemies

10. May all our Citizens be Soldiers, and all our Soldiers Citizens

11. Concord, Wisdom and Firmness to all American Councils

12. May our Country always be prepared for War, but disposed to Peace

13. Liberty and Happiness to all Mankind ${ }^{127}$

This toast encapsulates Sarah's core beliefs. First and foremost is pride in a new country. The order of the toast demonstrates Sarah Jay's political awareness and understanding of the male dominated public political sphere: she understood the dynamics of realpolitiks. But this is no empty toast. It serves as a warning to potential enemies of the liberated colonies: all citizens are soldiers, all soldiers citizens. In her hope for a lasting peace, she also warns that the country shall always be prepared for war. Although Sarah Jay was not able to deliver the toast, it is the content that is important. Throughout the war Sarah Jay remained a steadfast Whig, never doubting the course her father, husband, and many others set for the colonies. Mrs. Jay exhibited a moral heroism from the strictures of her place in society while abroad through her personal sacrifices. This toast was not only a reaffirmation of her steadfast devotion and loyalty to

\footnotetext{
${ }^{126}$ Alsop, 272.; Roberts, 170-71.

${ }^{127}$ Morris, in Unpublished Papers, Vol. 2, 581. A copy of the toast is reproduced here.
} 
her country, but it also stands as a symbolic understanding of Sarah's beliefs that her own sacrifices were not made in vain. Even if Sarah had been present at the ball it is doubtful she would have delivered the toast, because such an activity fell within the province of men. The toast was delivered by her husband, John.

Sarah Jay hoped to return to America soon after the signing of the Treaty of Paris, but the settling of political and business matters took John Jay many more months. Sarah Jay was concerned they might have to return to Spain to fulfill financial and political obligations. She did not want to see Carmichael who was still in Spain. Nor did she want want to return to the country where she had been so unhappy. She believed that Carmichael was the "only American who is capable of enjoying himself there" and "for all my country-men I know not his equal for duplicity of soul, or one who can so readily smile upon \& court the man he hates or despises, or fawn upon the man who treats him with contempt." ${ }^{\text {128 }}$ Carmichael's duplicitous nature made his character a perfect match for the Spanish court. ${ }^{129}$

John Jay continued to believe Carmichael was a spy for the British and Sarah blamed her estrangement from Brockholst on his influence. Both Sarah and John Jay knew of Carmichael's past. His entire life raised suspicion. At the outbreak of the American Revolution the Marylander was living in England. Volunteering his services to Silas Deane in 1776 he served as his secretary of legation in France until Arthur Lee and the French foreign minister, Vergennes, questioned his loyalty. Benjamin Franklin and Silas Deane, who were not convinced of his guilt, made arrangements for Carmichael to return to America, where he entered Congress as a representative of Maryland. $\mathrm{He}$

\footnotetext{
${ }^{128}$ SLJ to CWL, 16 July 1783, in Selected Letters, 136-38.

${ }^{129}$ Ibid.
} 
resigned from Congress in 1779 to accompany the Jays abroad. In 1783, Carmichael became the first official representative to Spain.

Throughout the Jays' mission to Spain Carmichael acted improperly: he assumed more authority than was granted to him by John Jay, he often spoke of matters that were not his to discuss, and mishandled funds at least once. Eventually John Jay forbade Carmichael to copy confidential reports for fear that he would use the information for his own purposes. There was no hard evidence against Carmichael, which prevented Jay from charging him with treason. In 1794 Carmichael was recalled to America under suspicion of treason, but died before he left Madrid. According to Richard B. Morris, modern day evidence supports John Jay's conclusion: Carmichael was an agent employed by the British government. ${ }^{130}$

In her letter Mrs. Jay continued her scathing recriminations of Carmichael and of Spain, and it is noteworthy that what seems to offend her the most was the lack of integrity and character she observed, not necessarily that points of view might differ. She wrote that Carmichael, and others like him, were able to "indulge any of their propensities unobserv'd by their more virtuous country-men" ${ }^{, 131}$ in Spain. What she meant is unclear, but the insult is not. She was glad these gentlemen could now find positions abroad for if they remained at home in America they could only defame "true patriots. ${ }^{" 132}$ This letter touches the borders of the public realm by acidly disparaging Carmichael, personally and politically, and by drawing political conclusions. At the end of the letter she apologizes and writes "I've transgress'd the line I propos'd to observe in

\footnotetext{
${ }^{130}$ Morris, in Unpublished Papers, Vol. 2, 769-770.; JJ to William Carmichael, 27 June 1780, in Unpublished Papers, Vol. 2, 777-780.

${ }^{131}$ Ibid.

${ }^{132}$ Ibid.
} 
my correspondence by dipping into politicks..."133 It should be noted that the line she transgressed was one she set for herself. Although she apologized for writing of politics her excuse is that her "country \& my friends possess so entirely my thoughts that you must not wonder if my pen runs beyond the dictates of prudence when engaged by those subjects." ${ }^{134}$ She was motivated by her loyalty to her country and to her friends. Both are virtues that pertain to the domestic realm. Sarah Jay was a person of integrity and honor who had little tolerance for those who lacked those qualities.

The Jays finally arrived in New York on July 24, 1784. Although she enjoyed the final years abroad, she was wearied from the experience. She learned valuable lessons in France on politics and culture, on the role of elegance and the political importance of society. These lessons would prove crucial to her successful endeavors to advance her husband's career and to make the Jays the uncontested leaders of New York society. The knowledge she garnered abroad served her well in her domestic role as wife to John Jay in the years to come. ${ }^{135}$

\footnotetext{
${ }^{133}$ Ibid.

${ }^{134}$ Ibid.

${ }^{135}$ Birmingham, 53.; Ellet, 63.; JA to Abigail Adams, 4 February 1783, in The Book of Abigail and John: Selected Letters of the Adams Family, 1762-1784, ed. L.H. Butterfield, Marc Friedlaender, and Mary-Jo Kline (Boston: Northeastern University Press, 1975), 340-41.
} 
Chapter Three: The Queen of America's Return 
Nine months after the September 1783 signing of the Treaty of Paris, John and Sarah Jay returned home to a well-deserved triumphant reception. After years wrought with uncertainty and sacrifice the Jays sailed from England on June 1, 1784 on a fair weather journey. It was a study in contrast to their initial Atlantic crossing that was beset by storms as they sailed into an uncertain future, hoping for the goodwill of an unsympathetic Spanish monarch. This peaceful crossing home was a brief hiatus between the brilliant success of the Treaty of Paris and the advent of a new series of rigorous and overwhelming challenges that accompanied the building of a new nation.

While in Europe the Jays sacrificed much to achieve the ambitious goal of liberating the United States from monarchical rule. Nation building was to prove no less challenging. Displacing a perceived tyrant brought liberty, but also created a cultural and political vacuum. Strong foundations were required to support the new political and social institutions, which were needed not only to govern the new nation, but also to withstand unforeseen threats to stability and unification. If the Republic was to be stable and resilient the country needed a new political, cultural, and national identity. ${ }^{136}$

Sarah Jay was instrumental in creating a new social context among the powerful and elite that became an informal policy conduit. Sarah Jay creatively applied the lessons learned in Europe to the coalescing American political and social scene to insure the Jays' place as power brokers and persons of influence. In addition to her ongoing support of her husband and their political agenda, she also fulfilled her traditional role within the domestic sphere by caring for her children and overseeing the daily affairs of

\footnotetext{
${ }^{136}$ Birmingham, 53.
} 
the household and family finances, as she kept her absentee husband apprised of any pertinent political information. ${ }^{137}$

During the next decade and a half John Jay was occupied in rebuilding a legal practice after a long absence. Jay served as a lobbyist, chief justice of the Supreme Court, negotiator of the Jay Treaty, governor of New York, and as diplomatic envoy to England. He was the New York delegate to Congress and a member of the New York convention to consider the ratification of the Constitution. ${ }^{138}$ Sarah Jay helped her husband achieve his ends, which were also her own, in many traditional ways. Her femininity and propriety was never challenged. She established her family's place in society by entertaining dignitaries, which helped to assure John's place as a political leader. Sarah's entertaining was an effective way to secure political allies and raise the status of the fledgling country in the eyes of foreign diplomats. She did not challenge her assigned gender role, but instead worked within its bounds to expand her and her family's position within society. By doing so Sarah Jay effectively furthered her husband's political and diplomatic career, while gaining a vestige of power herself. ${ }^{139}$

Sarah Jay relieved John Jay of the burden of making household decisions when he was involved in business affairs, judicial matters, political concerns, or diplomatic missions. In addition to handling household affairs, Sarah Livingston Jay kept her oftenabsent husband abreast of important political developments such as those that occurred during his race for the governorship of New York. Sarah Jay's activities in the domestic realm freed John to pursue his political and diplomatic career without hindrance. ${ }^{140}$

\footnotetext{
${ }^{137}$ Ibid.

${ }^{138}$ Freeman, 21-23.

${ }^{139}$ Roberts, 233-234.; Ellet, 63-75.

${ }^{140}$ Monaghan, 325, 327-28, 405.
} 
When John traveled, Sarah Jay often remained home, but there were several key differences between these separations and those she experienced abroad. In New York, she was supported by the extensive Livingston family network and was able to enjoy her children. Even with John gone, Sarah was fully occupied with the day-to-day operation of the household and was responsible for a wide range of entertaining. Her demanding responsibilities did not make the separation from her beloved husband any easier emotionally and once again she exhibited the moral heroism she exuded while abroad by facing and overcoming many obstacles. ${ }^{141}$

The Jays envisioned a strong and free United States. They were part of a broad and complex network that encompassed the social and political elite of the new nation. Much of the work that was required to maintain the vigorous pace and demands of the Jays' day-to-day private and public lives fell to Sarah Livingston Jay, who realized socializing was an important aspect of diplomacy. Mrs. Jay entertained political allies and enemies, as well as foreign dignitaries. The house, the invitation lists, the food, the dinner parties, and even the dress codes were specifically tailored to cater to the wealthy, impress the doubtful, and remind those who also sought power where it was to be found.

Upon their return from Europe the Jays took up residence at number eight Broadway in New York City. The elegant and sophisticated architecture of the house suited the Jays' purpose. There they entertained politicians, foreign diplomats, friends, and family on a grand scale. In accordance with propriety and the typical design of the day there were two dining rooms, one for large and formal affairs, and one that was used for informal occasions and family gatherings. There were two parlors, one in front and

\footnotetext{
${ }^{141}$ Freeman, 227.; On building of the residence and handling of expenses see SLJ to JJ, 7 July 1794, 227-28 and SLJ to JJ, 2 August 1794, 229-30 and SLJ to JJ, 27 September 1794 and SLJ to JJ, 25 October 1794, 235-38, in Selected Letters.
} 
one in the back, with the front parlor used for formal occasions and the back parlor for more intimate receptions. The house also contained a ballroom and a number of themed rooms, such as one containing magnificent tapestries and another decorated with damask. Every room stood in silent testimony to the wealth, influence, and sophistication of the Jays. $^{142}$

John and Sarah Jay understood that the most effective way to influence valuable political allies was to cultivate their trust in a relaxed and friendly atmosphere. Sarah Jay planned every detail of their social affairs. Mrs. Jay designed her famous dinner parties with a keen awareness of the political milieu of the day. The parties allowed politicians to heal old injuries inflicted by the bitter rivalries of the previous decade, and to rehabilitate reputations that were damaged during the course of the war. Such social events helped bridge certain societal chasms and factional lines that existed in the upper echelons of society. This helped ease tensions and kept the powerful and influential united in their interests and visions for the future. The dinners preserved the political alliances forged by the necessities of war that threatened to dissolve in the relative tranquility of peace. This was vital during a time when the fledgling nation was most vulnerable to the stresses created by independence and the absence of a predictable and reliable international presence. ${ }^{143}$

Sarah Jay's Invitations to Dinner and Supper, which was published in 1787 and read avidly by the public, showed that she entertained men and women from a broad range of constituencies. The list crossed ethnic lines by including those from Dutch, Spanish, English, and American families. It also crossed religious boundaries by

\footnotetext{
142 Birmingham, 54.

${ }^{143}$ Birmingham, 61.; Roberts, 233-34.
} 
including Presbyterians, Episcopalians, Quakers, and members of the Dutch Reformed Church. The dinner parties brought together Whigs and Tories in a congenial and relaxed setting. The list of distinguished guests even included John Alsop, the diehard antirevolutionist who refused to sign the Declaration of Independence, and British officers, such as Jacob Schieffelin. Mrs. Jay, wise in the art of intrigue and political manipulation, often invited family members to help promote an affable and agreeable environment. Such a relaxed atmosphere helped keep tempers in check and propriety foremost in the minds of the more aggressive guests. ${ }^{144}$

The names that comprised Sarah Jay's Invitations to Dinner and Supper belonged to some of the wealthiest, most influential, and intelligent members of late eighteenthcentury America. These dinners permitted notables to mingle, and encouraged the free exchange of ideas in a relatively safe and supportive atmosphere in which alliances were formed and opinions influenced. Mrs. Jay's Dinner and Supper list was also unusual because it included a dozen doctors and clergymen. Towards the end of the eighteenth century men of these professions were rarely, if ever, invited to such distinguished functions. ${ }^{145}$

A typical dinner took place on January 10, 1788. It included members of the Continental Congress such as Charles Thomson, secretary of the Congress from 17741789 and representatives Daniel Huger, John Armstrong, Nicholas Gilman, James Madison, and Cyrus Griffin. Also invited that day were Don Diego de Gardoqui, Spanish charge d'affaires and such clerics as the New York Episcopal Bishop, Samuel Provoost and Minister Pieter Johan van Berckel from the United Netherlands. Other distinguished

\footnotetext{
${ }^{144}$ Birmingham, 54, 61.; Ellet, 73-75.

${ }^{145}$ Cleveland Armory, Who Killed Society? (New York: Harper \& Brothers, Publishers, 1960), 115.
} 
guests were Alexander Hamilton, co-author with John Jay and James Madison of The Federalist Papers and member of the New York State Assembly, Robert R. Livingston, the first Chancellor of New York and former secretary for foreign affairs, Colonel Aaron Burr, a member of the New York State Assembly, General Henry Knox, secretary of war 1785-1794, and William Duer, secretary of the Board of the Treasury 1786-1789. ${ }^{146}$

While Sarah Jay oversaw the entertaining, John Jay served as secretary of foreign affairs, a delegate to Congress, vice chancellor of the University of the state of New York, and was responsible for establishing the New York Society for Promoting the Manumission of Slaves. Although his numerous responsibilities had taken a toll on his health, John Jay again served his country as a member of the New York convention to decide whether or not to ratify the Constituion of the United States. ${ }^{147}$

Debates raged over the ratification of the Constitution and both the Jays and the Hamiltons used dinner parties to shamelessly lobby New York convention delegates who held the future of the nation in their sometimes less than competent hands. In May of 1788 South Carolina became the eighth state out of the nine needed to ratify the Constitution. Even with the approval of nine states, there would be no union without the populous states of New York and Virginia. John Jay wished for the nation to grow and prosper, often challenging writers who championed states' rights over those of the nation. As a diplomat, Jay was aware that the United States had to present a strong, united front to the world. Disaster, he believed, would be the result of disunion. John Jay and Alexander Hamilton's lobbying techniques and collaboration on the Federalist Papers with James Madison helped to win the necessary majority in both states. During the

\footnotetext{
${ }^{146}$ Freeman, 179.

${ }^{147}$ Freeman, 22.
} 
1790's, the constitution was ratified in New York with the help of the Federalist Papers. The Federalists, including John Jay, also lobbied for the reestablishment of commercial ties with Great Britain. Jay believed it was necessary to maintain neutrality in European conflicts, while building up military strength. Only thus could the United States survive. ${ }^{148}$

Before and after the constitutional convention the new Republic took a dim view of the political pomp that characterized European diplomacy: foreign diplomats and travelers of import used to strict protocols and lavish receptions from their host countries found themselves at a loss in the newly united states. Sarah Jay's dinner parties and receptions were the exception and filled the pressing need for the unofficial but lavish social interactions that allowed an exchange of propositions and ideas not otherwise possible in a more formal setting. Mrs. Jay used her European experiences to create the expected ambiance for diplomats. Her dinner parties allowed distinguished guests to be received and treated in a fashion similar to that found in royal courts abroad, yet were a constant reminder that the new country was a democracy. It was a clever balance that was to prove brilliant in conception and execution.

The couple was always polite, always considerate, always hospitable to those they invited to their home. Their generosity and refinement made them admired and popular pillars of the community. It was usual for gracious visitors to attempt to bestow a gift on either Sarah or John. Both refused to accept any gifts, unless approved by Congress.

\footnotetext{
${ }^{148}$ Freeman, 22.; Roberts, 223-25.; Reginald Horsman, The Diplomacy of the New Republic, 1776-1815 (Arlington Heights, Illinois: Harlan Davidson, Inc., 1985), 39, 58, 71.
} 
They believed if they accepted gifts it could be construed as an act of impropriety and lead to accusations of favoritism. ${ }^{149}$

To help ensure that her dinners exuded the expected degree of elegance and sophistication guests found in the salons of France or Spain, Jay employed a gifted French chef who accompanied the Jays on their return to America. This kind of extravagance was an almost unheard of luxury in post-war America. The menus for her famous dinners boasted tempting dishes created from domestic, rare, and exotic foods. Every dinner included multiple courses of sumptuous offerings of fresh lobster, beef, mutton, lamb, veal, fowl with truffles, pies, puddings, custards, ice creams, jellies, domestic fruits and exotic fruits like bananas and pineapples, pastries, éclairs, candies of all kinds, petit fours, cruellers, and pound cake. The food was exquisite and so well prepared that the French Minister, the Count de Moustier, who was notorious for bringing his own chefs with him to prepare his food when calling, left them at home when dining with the Jays. ${ }^{150}$

Sarah Jay was always exquisitely dressed and took full advantage of the fashion expertise she gleaned while in Europe. While in France she was introduced to the finest milliners and dressmakers, whom she called upon to create fantastic dresses and accessories. While in Paris she forwarded much of her wardrobe to America in preparation for the social functions she knew she would be expected to perform there. These articles included dresses, gloves, hats, stockings, ribbons, and spectacular dresses. These fine clothes amazed and raised the aspirations of those at home that had been reduced to plain broadcloth or homespun by the war. One of Sarah Jay's ball gowns was

\footnotetext{
${ }^{149}$ JJ to Don Diego Gardoqui, 4 October 1785, 172 and JJ to DDG, 1 March 1786, 173-74, in Selected Letters.

${ }^{150}$ Birmingham, 55-56.;
} 
made from Chinese silk with real woven peacock feathers. Another elegant creation contained so many layers of Alencon lace that it weighed almost twenty pounds. ${ }^{151}$

Abigail "Nabby" Adams was frequently invited to the Jays' dinners. One of the dinners she attended was composed of "the whole corps diplomatique" and Mrs. Adams wrote, "Mrs. Jay dresses showily, but is very pleasing on a first acquaintance..." and that "The dinner itself was a la Francaise, and exhibited more of European taste than I expected to find." ${ }^{152}$ Mrs. Jay’s style of dress, her mannerisms, and her use of foreign cuisine had the desired effect upon those who dined at her home. Most were impressed, some were jealous, but none questioned the influence and power of the Jays.

By the 1790's many New York hostesses gave lavish parties and entertainment became almost a competitive art form. It symbolized social standing and power within the new country. Sarah Jay helped to create a new social context through entertaining that was adopted by the elite. Many of the nation's foremost wives-including Abigail Adams, Lucy Knox, and Martha Washington-held weekly receptions and dinners. Entertaining became a premiere political tool, one that the wives of politicians and would-be men of influence were forced to master in their domestic roles. Sarah Livingston Jay was one of the first to use dinner parties to elevate her family. ${ }^{153}$

As Sarah Jay established herself as a hostess and social leader, John Jay continued to advance his career. On September 29, 1789, John Jay was appointed as the First Chief Justice of the Supreme Court of the new nation. Under the new constitution Sarah Jay

\footnotetext{
${ }^{151}$ Birmingham, 53.

152 Abigail Adams Smith to AA, 20 May 1788, in Selected Letters, 167; Rufus W. Griswold, The Republican Court: American Society in the Days of Washington (New York: D. Appleton and Company, 1854), 91-92.

${ }^{153}$ Freeman, 162-164.; Carl Holliday, Woman's Life in Colonial Days (Boston: The Cornhill Publishing Co., 1922), 311.
} 
was left home while John was away serving the nation and traveling the court circuit. His circuit often lasted twelve weeks, at the end of which he returned home for a few brief weeks, and then he was off again. This grueling and hectic regime of travel and separation lasted for four years.

In 1793 Congress, heeding numerous complaints from the judiciary, decided to rotate the judges from circuit to circuit and appointed district judges to aid them in their tasks. Just before John's appointment as Chief Justice of the Supreme Court, Sarah gave birth to a son, William, on June sixteenth. She gave birth to Sarah Louisa almost three years later on February 20, 1792. Alone and with two young children and three older children to care for, Sarah was more than busy. ${ }^{154}$

Sarah Jay's letters serve as a measure of how greatly she missed John while he was away on his constant circuits. She wrote, "I shall continue to write every post..." and urged him to remember to write to her as well. ${ }^{155}$ Many of the letters were filled with the gossip of the day, and her social activities. She almost always included something about the children and their health to reassure the distant father all was well. She informed him when the children were inoculated or suffered from minor illnesses. Sarah also suffered from fevers and bouts of rheumatism. ${ }^{156}$

In 1792 a reluctant John Jay agreed to enter the election for Governor of New York, running against Aaron Burr and the incumbent George Clinton. Though he agreed to run, he refused to take part in campaigning. The election was a long, bitter struggle for

${ }^{154} \mathrm{JJ}$ to GW, 6 October 1789, in Selected Letters, 188.; Monaghan, 21-23.

${ }_{155}^{155}$ SLJ to JJ, 3 November 1790, in Selected Letters, 192-93.

${ }^{156}$ SLJ to JJ, 28 November 1790, 194-95 and SLJ to JJ, 29 April 1792, 205-06, in Selected Letters.; SLJ to JJ, 22 April 1792, in Selected Letters, 204. The children were often sick with colds or indigestion, but occasionally were seriously ill, such as when Peter Augustus and Nancy had mumps. They recovered, but her letter describing their illness after the fact demonstrates her wish not to worry him with something he could not change; SLJ to JJ, August 1787, in Selected Letters, 191. There are many letters to John Jay describing her bouts with illness while John was away on business or circuit riding. 
the three hopefuls. George Clinton had been Governor of New York for fifteen years and refused to be ousted easily. Although John Jay was away from home for most of the campaign, Sarah Jay found herself in the midst of a mudslinging contest, with her husband at its center. Throughout the ordeal Sarah Jay was able to keep her absentee husband apprised of developments largely due to her social connections. ${ }^{157}$

The newspapers of the day were filled with arguments either for or against a particular candidate. One paper claimed Clinton held more power in New York than the king did in England. Another declared that John Jay did not deserve credit for the Treaty of Paris since many others were instrumental in negotiating the peace. Since John Jay's character was unimpeachable, the Clintonians attempted to portray him as a haughty aristocrat, no better than the nobility of England and one who would only condescendingly lower himself to take the position if elected. In contrast, Clinton portrayed himself as one of the common people, a man of humble origin who was accustomed to hard work, toil, and sweat. ${ }^{158}$

On Election Day it appeared that the vote was going for John Jay, even though the ballots of several counties were slow to arrive at the office of the Secretary of State, where a board of twelve canvassers then performed an official count of the votes. The Clintonions, however, refused to concede the race. Sarah Jay kept her husband apprised via written correspondence of the votes as they came in or were announced in the newspapers. Her letters reflect her keen understanding of the political network and rampant intrigues. Few women of that era could claim such an understanding of the law and its inner workings. Sarah hoped John would be pleased to learn he had the majority

\footnotetext{
${ }^{157}$ Monaghan, 325, 327-28, 405.

${ }^{158}$ Ibid, 328-9.
} 
vote in New York and Westchester County, although she was somewhat worried about the votes in Otsego County. ${ }^{159}$

The situation in Otsego raised Mrs. Jay's fury. Her brother, Brockholst, had never forgotten his confrontation with the Jays during the Spanish debacle and after the deaths of their parents, William and Susannah, the hostility between Brockholst and the Jays had finally come to a head. Several Livingstons, including Brockholst, provided Clinton with a way to have the votes discarded in Otsego County, where John held a majority of about 400 votes. This county was crucial to the outcome of the election. The renegade Livingstons, using a loophole in the law, claimed that the Otsego sheriff's term expired, even though he continued to perform his duties until his successor was trained. ${ }^{160}$ Part of the sheriff's duties included delivering the ballots. The sheriff did perform his duties in accordance with the law, however, the Livingstons "wiggled" the law by claiming there was no official sheriff to deliver the ballots and therefore the votes should be excluded.

Sarah Jay was livid at the spurious attempt to exclude the votes and even more enraged with her relatives. In a letter to John she wrote, "Oh how is the name of Livingston to be disgraced!"161 Mrs. Jay understood how crucial the Otsego votes were to the election and felt betrayed by members of her own family. She called Brockholst and his associates, "shameless men, blinded by Malice Ambition \& interest." "162 She believed they "conducted themselves with such indecency during the election $\&$ daily

\footnotetext{
${ }^{159}$ SLJ to JJ, 2 June 1792, in Selected Letters, 209-10.; Monaghan, 333.

${ }^{160}$ Monaghan, 333-35.; SLJ to JJ, June 10 1792, 210-12. The Otsego Sheriff performed his duties in regard to the election to the letter of the law. Once he received the sealed ballots of Otsego from the inspectors of the election he handed them over to a special deputy with all haste. The deputy then immediately delivered them to the Office of the Secretary.

${ }^{161}$ SLJ to JJ, 10 June 1792, in Selected Letters, 210-12.

${ }^{162}$ Ibid.
} 
since the Canvassing of the votes, as to open the eyes of every one respecting their views in their opposition to you." ${ }^{, 163}$ Mrs. Jay kept her husband fully informed of the election and was able to give full vent to her ideas in her correspondence.

Mrs. Jay's letter goes on to discuss the "Canvassers", writing that she believed they would side eight with Clinton and three with Jay. The Canvassers, to protect themselves from public criticism, asked the opinion of Aaron Burr and Rufus King. Sarah Jay used her extensive network of connections and found that King, siding with Clinton, wanted to exclude the Otsego votes. Burr walked a fine line, saying the votes were illegal if there was no Sheriff to deliver them, but that Clinton should have chosen a sheriff. Sarah Jay was enraged at Clinton's attempt to hijack the election, with the help of the Canvassers:

Should the Canvassers...decide against the privileges of the People, \& instead of suffering them to choose a Governor, take upon themselves to give them one, it will occasion great agitation throughout the State. I am satisfied that the sentiments of the people are with you, whether you are, or are not Governor, it appears that you are the choice of the people. ${ }^{164}$

Sarah Livingston Jay was an astute student of the American political process and well understood the political realities of the new Republic, despite her lack of official participation. Part of her outrage was her feeling of betrayal by members of her family. However, more serious to Sarah was the betrayal of the most basic democratic principle: the right of the people to freely choose their elected officials. To Sarah Jay, discounting the Otsego votes was the worst form of betrayal.

Later that day word arrived that the Canvassers had also put aside the Tioga County votes, because a clerk delivered the votes when the deputy assigned to that

\footnotetext{
${ }^{163}$ Ibid.
}

${ }^{164}$ Ibid. 
County fell ill. Yet again, John Jay held a majority of the votes in Tioga County with a lead of just over a hundred. Sarah Jay told John she believed that "The dejection, uneasiness \& dissatisfaction that prevails, casts the darkest Odium upon our Shameless Governor, while it makes your light shine still brighter than ever." ${ }^{\text {165 }}$ The entire city was in an uproar. The people were furious that their votes were being turned aside for political maneuverings of the most obvious sort. The election was concluded: Clinton remained in the seat of power.

Sarah Jay wrote her husband that, "There is such a ferment in the City that it is difficult to say what will be the consequence..." and that "People are running in continually to vent their vexation." 166 The city was in turmoil and only carefully crafted letters by John Jay to outraged friends and to the papers avoided riots. Sarah Jay once again found herself in a difficult position without the support of her husband to see her through. Without his presence she was forced into overseeing the repercussions of the election in his stead, while he wrote letters from afar.

John did not seem upset by the results of the election and wrote "...that injustice has taken place does not surprise me, and I hope will not affect you very sensibly." ${ }^{167}$ John believed he had “...nothing to reproach myself with in relation to this event, it shall neither discompose my temper, nor postpone my sleep." ${ }^{\prime 68}$ His words ended the matter, at least within the extent of written correspondence. It was no doubt easier for him,

\footnotetext{
${ }^{165}$ SLJ to JJ, 10 June 1792, in Selected Letters, 210-12.; Monaghan, 334. The votes of a third county, Clinton, were eventually excluded as well because the Sheriff had delivered the ballots to a gentleman who was not deputized to receive them. In not one of the counties were ballots missing, had seals been broken, or was there a delay in their delivery.

${ }^{166}$ SLJ to JJ, 10 June 1792, in Selected Letters, 210-12.

$167 \mathrm{JJ}$ to SLJ, 18 June 1792, in Selected Letters, 212-13.

${ }^{168}$ Ibid.
} 
distracted by his circuit rides throughout the country, to maintain a calm demeanor about the situation. Sarah Jay found the matter more difficult to put aside.

Sarah Livingston Jay was fully aware of political happenings within New York. Mrs. Jay understood the mechanics of the election, the intrigues that made it impossible for her husband to win, and the ferment that almost tore the city apart after the election. Sarah Jay's political consciousness - first sparked as a child under the roof of the activist William Livingston — burgeoned during the American Revolution, as did that of many other women. This political consciousness continued to grow after the revolution. It did not halt because the war was over. Sarah Jay did not need to be redirected into the domestic realm, for like most women in that era, she had never challenged her role in society. After the war Sarah Jay gained further insights and understanding, and used that information to keep John informed of the election, once again using her domestic abilities, working within the confines of her station, to aid her absent husband by any means she could. In this case it was using her political knowledge to keep her husband informed of the gubernatorial election.

After his loss to George Clinton, John Jay continued to perform his duties as chief justice until 1794 when the United States of America was again on the brink of war with England. Jay was called upon to serve his country through his diplomatic prowess. Neither Great Britain nor the United States had honored the terms of the 1783 Treaty of Paris. Britain retained its forts in the Northwest Territory long after they were obligated to withdraw. The British Navy posed a constant threat to American merchant and trading ships on the high seas by refusing to allow them free passage to foreign destination ports. The Royal Navy also pressed American seamen into service on British ships. America 
failed to meet a number of the commitments outlined in the Treaty of Paris as well, most notably in their ill treatment of Tories and in not paying pre-war debts to British merchants. ${ }^{169}$

With war between America and England imminent, President George Washington asked the seasoned diplomat John Jay to forge another treaty with England. John agreed and after three days of debate Congress confirmed him as envoy extraordinary. Sarah again learned of her husband's appointment via the newspaper. Although she was pleased by the honor, she was upset by the impending separation and by the fact that she learned of it in the post along with the rest of the public. Of the appointment she wrote, "The Utmost exertion I can make is to be silent. Excuse me if I have not philosophy or patriotism to do more. I heard of the nomination yesterday, so did the Children."170

Sarah understood the urgency and importance of the mission and so she presented no argument against John's acceptance of the position, only regret at the separation. Jay knew she could not accompany her husband abroad this time. Although Peter Augustus, her oldest child, was a college graduate, she wanted to be near her four younger children. Since Sarah Jay was unable to accompany her husband, she requested John take Peter Augustus with him, writing it "would give him infinite pleasure \& me great consolation. ${ }^{.171}$

John Jay was not pleased by his wife's suggestion, writing that it did "not strike me forceably" and he did not believe the trip could afford Peter any real advantage.

\footnotetext{
${ }^{169}$ Berens, 133.; Freeman, 219.; Paul A. Gilje, Liberty on the Waterfront: American Maritime Culture in the Age of Revolution (Philadelphia: University of Pennsylvania Press, 2004), 142-43.

${ }^{170}$ Freeman, 220.; SLJ to JJ, 18 April 1794, in Selected Letters, 221-22.

${ }^{171}$ SLJ to JJ, 18 April 1794, in Selected Letters, 221-22. Sarah Livingston Jay had four children remaining at home with her: twelve year old Maria, eleven year old Nancy, five year old William, and two year old Sarah Louisa.
} 
Sarah Jay knew the trip would be an educational experience for her son before he took on an apprenticeship in a law office. Despite John's numerous objections to the idea, Sarah Jay was a master of persuasion. On May $12^{\text {th }}$, when the Ohio set sail for London, Peter Augustus was on board with his father. ${ }^{172}$

While John Jay was off negotiating the Jay Treaty with Lord Granville, Sarah Jay remained at home to oversee the household, the children, and the finances. She made decisions regarding the children's education, most notably when she enrolled Maria in the Moravian Academy in Bethlehem, Pennsylvania. Men were the masters of families and usually made all major decisions, but John was not home. Her decision to send Maria to the Moravian Academy is perhaps indicative of the rise of "Republican Motherhood," the idea of educating women to educate the future citizens of the new Republic. It was a way to ensure women's burgeoning political thoughts remained in the domestic realm, by having them concentrate on educating their children. It gave women a feeling of usefulness and the ability to participate in the new country. Nancy Jay, in 1796, also became a student at the Moravian Academy. ${ }^{173}$

Sarah Jay was educated by private tutors when she was growing up, because institutions such as the Moravian Academy were scarce. Such academies, which provided an education on a par with male academies, only became fairly common in the

\footnotetext{
172 JJ to SLJ, 20 April 1794, in Selected Letters, 223-24. Eighteen year old Peter Augustus was a recent graduate of Columbia and had not yet entered into an apprenticeship in a law office, making it an ideal time for him to travel with his father. Although she does not write it, it is possible Sarah Jay hoped the trip together would make the two closer since John missed not only his early years, but much of his teens as a traveling Chief Justice.

${ }^{173}$ Kerber, 119-201, 235, 269, 283-87.
} 
1780 's. When the opportunity arose for her daughter to further her education, Sarah seized it and only informed her absent husband of her decision afterward. ${ }^{174}$

She also oversaw the work on the family's new residence in Bedford and kept her husband apprised of pertinent financial information. The improvements made on the property during this time included enlarging the farm manager's house and the construction of several mills. Sarah Jay assumed the financial responsibilities in her husband's absence and had full autonomy to make financial decisions. A shrewd financial manager, she kept her husband apprised of purchases and rises in stocks, the details surrounding the sale of land and the progress at Bedford. Although Sarah Jay had always worked side by side with her husband, John, she only assumed full financial responsibilities in his absence. ${ }^{175}$

In the fall of 1794 Sarah Jay encountered an unpleasant situation, which she did not convey to her husband. The incident illustrates Mrs. Jay's fortitude and reflects her strong personality. The farm manager at Bedford, Samuel Lyon, was supposed to see to the breaking of several horses. When the breaking of the horses continued to drag on she sent a polite letter to Lyon asking how much longer the job would take. The letter went awry and a Bedford man told Lyon that Sarah Jay fired him and would never pardon him for not seeing to the situation quickly enough. Lyons responded to the situation by writing Jay, "Madam, although I am your servant, I am not your slave."176

\footnotetext{
${ }^{174}$ Evans, E., 2. Interesting discussion of femme covert.; Evans, S., 57, 65. Evans goes on to write about the awesome responsibility mother's held in educating their children and how by this time children were no longer looked upon as full of sin and willfulness as they were before the Enlightenment, but as comprised of reason and the possibility of perfection.; SLJ to JJ, 11 October 1794, in Selected Letters, 233-34.; JJ to Nancy Jay, 8 June 1796, in Selected Letters, 254-55.

${ }^{175}$ Freeman, 227.; On building of residence and handling of expenses see SLJ to JJ, 7 July 1794, 227-28 and SLJ to JJ, 2 August 1794, 229-30 and SLJ to JJ, 27 September 1794 and SLJ to JJ, 25 October 1794, 235-38, in Selected Letters.

${ }^{176}$ Samuel Lyons to SLJ, 10 November 1794, in Columbia Online.
} 
Lyons wrote another letter the day after the first. Although much more civil and containing an offer of potatoes and turnips, it held no apology for the first letter. Sarah's response is an example of her astute handling of affairs and abilities of manipulation. She wrote Lyon's that he “... wounded the feelings of a lady who has invariably treated you with cordiality and politeness." ${ }^{\text {177 }}$ She went on to explain exactly what the first letter contained. Toward the end of the letter she wrote, "Though Mr. Jay could not but be aware of the many inconveniences, injuries, and anxieties, that would be the consequence of his acceptance of a mission three thousand miles from his family, yet I am well convinced...that... asperities from you, sir, to his solitary wife never entered his calculations." ${ }^{178}$ Samuel Lyon remained on the farm. Sarah Jay again handled the situation, although Lyon never apologized for his actions.

John Jay returned from England in May of 1795 to discover he had been elected Governor of New York during his absence. Clinton's actions during the last election sealed his fate and Jay went on to serve two terms and four years as Governor. John Jay retired from public life in 1800 , to live a quiet life with his ailing wife.

Sarah Jay, regularly plagued by arthritis, had suffered from what appeared to be a slight stroke in December of 1800. She stayed at Oak Hill, her sister's residence, to regain her health before joining her husband at Bedford in early December 1801. The Jays looked forward to spending their last years together, time so long denied them by their duties to public and country. Although Sarah's speech improved and she regained the use of her right hand and arm, she never fully recovered from her stroke. On May 28,

${ }_{178}^{177}$ SLJ to SL, 14 November 1794, in Columbia Online.

${ }^{178}$ Ibid. 
1802 Sarah Livingston Jay died, depriving the world of the "uncommon merits of the woman-the amiableness of the friend....and the elegant accomplishments of the Lady.”179

\footnotetext{
${ }^{179}$ Ellet, 82-3.; Freeman, 272. A printed copy of her obituary is reprinted on page 282 of Selected Letters and appeared in the New York Herald on Wednesday, June 2, 1802. I was not able to discover who wrote the obituary, for it is not included in Selected Letters and there is no reference to it in any of the other letters read that discussed her death.; JJ to Peter Augustus Jay, 8 December 1800, 272-73 and JJ to SLJ, 17 May 1801, 273 and SLJ to JJ, 27 May 1801, 273-74, in Selected Letters.
} 
Conclusion 
Sarah Jay's contributions to American history cannot be overlooked. Her patriotism brings to light factors that may be applied to other women's political involvement in the war and provides a deeper and richer understanding of the social dynamics of the Revolution. Mrs. Jay's many sacrifices during the American Revolution demonstrate her patriotism and belief in the cause for independence. After the war Sarah Jay's hospitality influenced American culture and politics. Sarah Jay's activities show that more women than previously believed participated fully in the American Revolution without rejecting traditional female roles.

Sarah Livingston Jay was a dedicated patriot who made significant contributions to the success of the revolutionary war. The only wife of a diplomat to travel abroad during wartime, Sarah suffered the constant absences of her husband, John, gave birth to two children while abroad and buried one on foreign soil. She endured uncomfortable traveling conditions, isolation, and an unrecognized status, as well as confrontations with family members and associates. These numerous personal sacrifices made on behalf of the American Revolution, combined with sentiments expressed within her voluminous correspondence, suggest that she possessed a keen political mind that fully developed during the revolution. This allowed her to exert an influence on the course of American political events, not just through her husband's elected positions and political appointments, but by using her social status to achieve political ends.

While her husband shaped the new country, Sarah Jay fulfilled her domestic obligations. She oversaw the household and family, hosted the obligatory entertaining, handled family finances and reserved time and energy for the political power struggles that affected her husband. Yet the Revolution was a catalyst for change in many areas. 
The budding political consciousness that women developed during the war years burgeoned for a time after the American Revolution. Many women actively participated in the public arena, yet they were not permitted to vote. Encouraged during the war, their participation and patriotism posed a new threat to social structures immediately following the conflict. This created a conundrum for the founding fathers after the American Revolution. No one knew exactly what the relationship between women and the state should be, but they knew that a true republic would be suffused with "all great, manly, and warlike virtures." 180 There was no allowance for domesticity, such as practiced by Sarah Jay, in this particular equation. Men still refused to believe that women had the intellectual capacity to participate in politics, yet women were participants in the war. ${ }^{181}$

The solution to this perplexing problem was a simple one. Political conservatives eventually directed women back into the domestic realm from whence they came. This was accomplished through the creation of a concept known as "Republican Motherhood," so well epitomized by Sarah Jay and her determination to provide her daughters with a good education. Theoretically, Republican Motherhood allowed women to participate in politics and the political process vicariously by placing responsibility upon women to educate the future voting citizens of America: their male children. Female children, like Maria and Nancy Jay, also had to be educated, for eventually they would become mothers and be responsible for the education of future citizens. It was a solution that redirected women's burgeoning political enthusiasms back into home and hearth, one that is demonstrated through Sarah Livingston Jay.

\footnotetext{
${ }^{180}$ Evans, S., as quoted on page 47.

${ }^{181}$ Kerber, 36.
} 
Republican Motherhood allowed women to function as political beings on some level, yet retain their social status and "respectability" as wives, mothers, and daughters. Republican Motherhood united the domestic and political realm, and permitted women to feel they were taking an active role in the formation of the country. It made logical sense. The Moravian Academy, which two of Sarah Jay's daughters attended, was only one among many female schools that sprang up throughout the states in the 1780 's. ${ }^{182}$

Sarah Livingston Jay did not melt quietly into the background delineated by Republican Motherhood. She remained within the realm of domesticity, but used her position within society to continue to influence politics. Although Republican Motherhood was designed to redirect women's political interests back into more "womanly" pursuits, Sarah Livingston Jay is an example of how that redirecting failed, for although she remained within the domestic realm and embraced the idea of Republican Motherhood by educating her daughters, the reality is that she extended her responsibilities by continuing to affect politics from within the realm of domesticity.

Despite Sarah Jay's ardent patriotism and her political acumen, she sought no external recognition or reward for her role. By Abigail Adams' estimation this was the true measure of a selfless patriot. Even so, Sarah Jay still honored the duties assigned to her because of her gender, but instead of working against it she used it to her advantage. Sarah Livingston Jay participated in the war and helped to form the country as fully as did her husband. She neither sought nor required recognition for her actions, which was true of most women of that era. Following in the tradition perpetuated by countless generations of women, Sarah Jay embraced the female role allotted her. She extended her influence indirectly through her husband and family.

${ }^{182}$ Evans, S., 60-65.; Kerber, 36. 
Sarah Jay was not typical of women during this period, her birth and education placing her in the top echelons of colonial society. Nevertheless, her ardent commitment to the American Revolution was shared by many women of all ranks, who clearly understood the issues and implications of the war. These women took positions that were often unpopular with society at large. Sarah's actions were neither unusual nor unpopular - indeed many women today follow the same course. What is unusual was her dedication to the cause and her understanding of politics and the issues involved. Her high level of intelligence aided her endeavors and she successfully worked within and expanded the realm to which she was confined. 


\section{Bibliography}

\section{Primary Resource Compendiums}

Ashton, Jean. The Papers of John Jay, 1745-1829. [webpage][November 24, 2004]

Columbia University; available from

$<$ http:www.columbia.edu/cu/lweb/eresources/archives/jay/>.

Butterfield, L.H., Marc Friedlaender, and Mary-Jo Kline., ed. The Book of Abigail and John: Selected Letters of the Adams Family, 1762-1784, Boston: Northeastern University Press, 1975.

Freeman, Landa M., Janet M. Wedge, Louise V. North., ed. Correspondence by or to the First Chief Justice of the United States and His Wife: John Jay and Sarah Livingston Jay, Jefferson, North Carolina: McFarland \& Company, Inc., 2005.

Jay, William, ed. The Life of John Jay: with Selections From His Correspondence and Miscellaneous Papers, Vol. 1. New York: J \& J Harper, 1833.

Jay, William, ed. The Life of John Jay: with Selections From His Correspondence and Miscellaneous Papers, Vol. 2. New York: J \& J Harper, 1833.

Morris, Richard B., ed. John Jay: The Making of a Revolutionary, Unpublished Papers 1745-1780, Vol. 1. New York: Harper \& Row, Publishers, 1975.

Morris, Richard B., ed. John Jay: The Winning of the Peace, Unpublished Papers 17801784, Vol. 2. New York: Harper \& Row, Publishers, 1980.

Prince, Carl E. and Mary Lou Lustig., ed. The Papers of William Livingston: July 1780April 1783, Vol. 4. New Brunswick and London: Rutgers University Press, 1987.

Prince, Carl E., Dennis P. Ryan, Brenda Parnes, and Mary Lou Lustig., ed. The Papers of William Livingston: January 1779-June 1780, Vol. 3. New Brunswick: Rutgers University Press, 1986.

Sedgewick, Theodore Jr., ed. A Memoir of the Life of William Livingston: Extracts From His Correspondence, and Notices of Various members of His Family, 1774-1790, New York: J \& J Harper, 1833.

\section{$\underline{\text { Secondary Resources }}$}

Alsop, Susan Mary. Yankees at the Court: The First Americans in Paris. New York: Doubleday and Company, Inc., 1982. 
Amory, Cleveland. Who Killed Society?. New York: Harper \& Brothers, Publishers, 1960.

Berens, John F. Providence and Patriotism in Early America, 1640-1815. Charlottesville: University Press of Virginia, 1978.

Birmingham, Stephen. America's Secret Aristocracy. Boston: Little, Brown \& Company, 1987.

Bohrer, Melissa Lukeman. Glory, Passion, and Principle: The Story of Eight Remarkable Women at the Core of the American Revolution. New York: Atria Books, 2003.

Booth, Sally Smith. The Women of '76. New York: Hastings House, 1973.

Bridenbaugh, Carl. The Spirit of '76: The Growth of American Patriotism Before Independence. New York: Oxford University Press, 1975.

Cott, Nancy F. and Elizabeth H. Pleck. "Introduction" In A Heritage of Her Own: Toward a New Social History of American Women, edited by Nancy F. Cott and Elizabeth H. Pleck, 13-17. New York: Simon and Schuster, 1979.

Earle, Alice M. Colonial Dames and Good Wives. New York: The Macmillan Company, 1895.

Ellet, Mrs. <?>. Queens of American Society. New York: Charles Scribner \& Company, 1867.

Evans, Elizabeth. Weathering the Storm: Women of the American Revolution. New York: Charles Scribner's Sons, 1975.

Evans, Sara M. Born for Liberty: A History of Women in America. New York: The Free Press, A Division of Macmillan, Inc., 1989.

Ferling, John. A Leap in the Dark: The Struggles to Create the American Republic. Oxford: Oxford University Press, 2003.

Gilje, Paul A. Liberty on the Waterfront: American Maritime Culture in the Age of Revolution. Philadelphia: University of Pennsylvania Press, 2004.

Griswold, Rufus W. The Republican Court: American Society in the Days of Washington. New York: D. Appleton and Company, 1854.

Holliday, Carl. Woman's Life in Colonial Days. Boston: The Cornhill Publishing Co., 1922. 
Horsman, Reginald, The Diplomacy of the New Republic, 1776-1815 Arlington Heights, Illinois: Harlan Davidson, Inc., 1985.

Keller, Rosemary. Patriotism and the Female Sex: Abigail Adams and the American Revolution. New York: Carlson Publishing Inc., 1994.

Kerber, Linda K. Women of the Republic: Intellect \& Ideology in Revolutionary America. New York: W.W. Norton \& Company, 1986.

Kierner, Cynthia A. "From Entrepreneurs to Ornaments: The Livingston Women, 16791790" In The Livingston Legacy: Three Centuries of American History, edited by Richard T. Wiles, 336-359. Taconic Region: Bard College, 1987.

McCurdy, Claire. "Sarah Van Brugh Livingston Jay, 1756-1802” In Past and Promise: Lives of New Jersey Women, edited by Joan N. Burstyn, 24-26. New Jersey: The Scarecrow Press, Inc., 1990.

Monaghan, Frank. John Jay: Defender of Liberty. New York: The Bobbs-Merrill Company, 1935.

Norton, Mary Beth. Liberty's Daughters: The Revolutionary Experience of American Women, 1750-1800. Boston-Toronto: Little, Brown and Company, 1980.

Roberts, Cokie. Founding Mothers: The Women Who Raised Our Nation. New York: HarperCollins, 2004.

Salmon, Marylynn. "The Limits of Independence: 1760-1800” In No Small Courage: A History of Women in the United States, edited by Nancy F. Cott, 109-178. Oxford, Oxford University Press, 2000.

Scholoesser, Pauline. The Fair Sex: White Women and Racial Patriarchy in the Early American Republic. New York: New York University Press, 2002.

Wiesner-Hanks, Merry E. Gender in History. Oxford: Blackwell Publishers, 2001.

Young, Alfred. "The Women of Boston: "Persons of Consequence" in the Making of the American Revolution, 1765-1776." In Women and Politics in the Age of the Democratic Revolution, edited by Harriet B. Applewhite and Darline G. Levy, 181-218. Ann Arbor: The University of Michigan Press, 1990. 